\title{
Pressure drop through platinized titanium porous electrodes for ceriumbased redox flow batteries
}

\author{
Luis F. Arenas ${ }^{\mathrm{a}}$, Carlos Ponce de León ${ }^{\mathrm{a}}$, Frank C. Walsh ${ }^{\mathrm{a}, *}$ \\ ${ }^{a}$ Electrochemical Engineering Laboratory, Energy Technology Group, Faculty of \\ Engineering and the Environment, University of Southampton SO17 1BK, UK. * \\ Author for correspondence: F.C.Walsh@soton.ac.uk
}

\begin{abstract}
Pressure drop, $\Delta P$, in redox flow batteries is linked to pumping costs and energy efficiency, making the characterization of hydraulic properties of electrodes a necessity during scale-up. In this work, the $\Delta P$ at diverse platinized titanium electrodes for the positive reaction in Ce-based redox flow batteries is reported vs. mean linear electrolyte velocity as measured in a rectangular channel flow cell. Darcy's friction factor and permeability vs. Reynolds number are calculated. Average permeability values are: $7.10 \times 10^{-4} \mathrm{~cm}^{2}$ for Pt/Ti mesh, $4.45 \times 10^{-4} \mathrm{~cm}^{2}$ for Pt/Ti plate + turbulence promoters, $1.67 \times 10^{-5} \mathrm{~cm}^{2}$ for $\mathrm{Pt} / \mathrm{Ti}$ micromesh, and $1.31 \times 10^{-6} \mathrm{~cm}^{2}$ for $\mathrm{Pt} / \mathrm{Ti}$ felt. The electrochemical volumetric mass transport coefficient, $k_{\$} A_{\&}$, is provided as a function of $\Delta P$. In flow-by configuration, Pt/Ti felt combines high $k_{\$} A_{\&}$ values with relatively high $\Delta P$, followed by $\mathrm{Pt} / \mathrm{Ti}$ micromesh. $\mathrm{Pt} / \mathrm{Ti}$ mesh and $\mathrm{Pt} / \mathrm{Ti}$ plate yielded lower $\Delta P$ but poorer electrochemical performance. Implications for cell design are discussed.
\end{abstract}

Keywords: cerium; electrochemical flow reactor; platinized titanium; porous electrode; pressure drop; redox flow battery.

\section{Introduction}

Three-dimensional platinized titanium (Pt/Ti) structures are the preferred electrodes for the conversion of cerium ions in electrochemical flow reactors. ${ }^{1}$ Following its use in mediated 
electrosynthesis, ${ }^{2,3}$ nuclear decommissioning, ${ }^{4}$ and disposal of hazardous organics, ${ }^{5}$ the $\mathrm{Ce}(\mathrm{III}) / \mathrm{Ce}(\mathrm{IV})$ redox couple has received attention in the field of electrochemical energy storage. The Zn-Ce redox flow battery (RFB) has a thermodynamic cell potential of $2.48 \mathrm{~V}$ and has been developed over more than a decade. ${ }^{6}$ Alternative systems have been proposed, such as V-Ce, ${ }^{7-10} \mathrm{~Pb}-\mathrm{Ce},{ }^{11} \mathrm{H}_{2}$-Ce half-fuel cells, ${ }^{12,13}$ and a Ce-Ce concentration cell. ${ }^{14}$ Previously, we have estimated the contribution of thermodynamic, kinetic and resistive components to the cell potential of the $\mathrm{Zn}-\mathrm{Ce} \mathrm{RFB}^{15}$ and established the electrochemical performance of diverse Pt/Ti electrodes in terms of the volumetric mass transport coefficient, $k \$ A \&$, from limiting current measurements. ${ }^{16}$ In this work, we report the hydraulic properties of $\mathrm{Pt} / \mathrm{Ti}$ porous electrode materials as described by the static pressure drop, $\Delta P$, produced in a cerium-containing flowing electrolyte.

The pressure drop through the electrodes of a RFB is directly related to its pumping power demand and hence to its overall energy efficiency. It is essential to measure such losses and to relate them to the electrochemical performance of the electrodes in order to achieve a successful and economical scale-up of the system. Pressure drop has been considered in RFBs since the initial developments at NASA, ${ }^{17,18}$ and in other types of electrochemical reactors and electrolyzers. ${ }^{19,20}$ Since, measurement and control of pressure drop has been undertaken in several RFBs. For instance, early work suggested intermittent pump action in order to increase the efficiency of the Fe/Cr RFB, ${ }^{21}$ although electrode 'starvation' and gas build-up should have required preventive measures. On the other hand, few experimental studies in utility-scale RFBs have been reported. One example is the pressure drop in brominepolysulfide stacks with 7,200 $\mathrm{cm}^{2}$ planar electrodes. ${ }^{22,23}$ The pressure drop in these stacks surpassed the predicted values for empty channels and displayed an exponential increase as a function of mean linear flow velocity 
due to constricted manifolds. In well-engineered utilityscale RFBs, energy losses due to electrolyte pumping can be expected to be under $5 \% .{ }^{24}$

More recently, the pressure drop and pumping losses in vanadium RFB stacks have been simulated, optimizing the dimensions of the carbon felt electrodes and other flow features in relation to shunt currents, ${ }^{25}$ and permitting the estimation of losses in a 40 cell stack. ${ }^{26}$ Optimization of pump operation related to the internal resistance losses in vanadium RFBs has also been performed based on the measured permeability of the carbon felt electrodes. ${ }^{27}$ The degree of compression of the felt in vanadium RFBs has an important effect on pressure drop, ${ }^{28}$ as well as electrolyte viscosity change over state of charge (SOC). ${ }^{29}$ Pump power losses for different types of bends, valves and tube diameters in the electrolyte circuit have been also considered. ${ }^{30}$ Pressure drop differences between the positive and negative half-cells can be substantial, ${ }^{31}$ and the cell design should aim to reduce them. Finally, it has been shown that interdigitated felt electrodes could reduce pressure losses in vanadium RFB stacks to $c a$. 30\% in comparison to conventional flow-by designs. ${ }^{32,33}$ It should be noted that most simulation results have not been validated by experimental data, creating a need for this type of studies.

Furthermore, the pressure drop in several recently proposed RFBs employing extremely viscous or non-Newtonian electrolytes has not received sufficient attention. Electrolytes based on ionic liquids, deep eutectics, slurries, 'flowing electrodes’ and suspensions (e.g. in Chakrabarti et $a l .{ }^{34}$ ) will significantly increase pressure drop, requiring either more permeable porous electrodes or possibly planar electrodes. For instance, relatively open reticulated vitreous carbon (RVC) electrodes were needed to permit the flow of a semi-solid electrolyte in a conceptual Li-air RFB. ${ }^{35}$ 
Pressure losses over RFB stacks can be appreciably higher than those predicted by the sum of the pressure drop at individual unit cells. ${ }^{17}$ The consumption of pumping power by a stack at a given flow rate and temperature increases as a result of tortuous or constricted manifolds, porous electrodes/turbulence promoters, long tubes/channels, small cross-sectional areas, abrupt changes in the flow direction, turbulence and electrolyte viscosity. The actual fluid flow through electrode channels in large stacks can deviate from ideal behaviour, due to material heterogeneities or incomplete flow development. ${ }^{36}$ Hence the significance of uniform porous electrodes and engineering tolerances. Although analytical estimation ${ }^{25}$ and computer fluid dynamics (CFD) simulation ${ }^{37}$ can certainly account for the expected ideal pressure drop in RFB systems, actual measurements over the built stacks remain as one of the main tasks required during pilot and full-scale testing.

\section{Pressure Drop and Electrode Performance}

The restriction imposed by porous materials to incompressible fluids as they flow through, can be described as the static pressure drop, $\Delta P$, vs. the mean linear electrolyte flow rate or an associated Reynolds number. Basic normalised indicators of hydraulic behaviour, such as Darcy's friction factor, $f^{*}$, and Darcy's permeability, $K$, can be calculated, assuming homogeneous, isotropic porous structures in steady state laminar flow. Other expressions can be more suitable for the description of fluid flow through highly porous media, such as the Ergun equation, ${ }^{38,39}$ or the Kozeny-Carman equation. ${ }^{40}$ The Kozeny-Carman equation considers pore size and has found use in characterizing carbon felts used in RFBs. Anisotropy in porous materials such as meshes with different orientation or felts having fibres aligned in preferential directions has to be considered. 
The Darcian flow rate employed in porous electrodes is the mean linear electrolyte flow velocity, $v$, past the electrode surface. This normalised figure considers the cross-sectional area, $A$-, and volumetric porosity, $\varepsilon$, of the porous material. The mean electrolyte flow velocity through the porous electrode is given by:

$v=\varepsilon A^{0} \underline{1}_{x}$

The pressure drop over the electrode as a function of mean linear electrolyte flow velocity or Reynolds number can be described by a power law, ${ }^{19,41}$ in the form:

$\Delta P=d R e^{6}$

Where the coefficient, $d$, and $R e$ exponent, $h$, are empirical constants.

Under full convective diffusion reaction control and steady state, the electrochemical performance of a porous electrode in an electrochemical flow reactor can be expressed, in turn, as the volumetric mass transport coefficient, $k \$ A \&,{ }^{42}$ which is the product of the average mass transport coefficient of the electroactive species dissolved in the flowing electrolyte, $k \$$, and the volumetric active area of the electrode, $A \&$. Close approximations of the required dimensions of the units cells and stacks in electrochemical reactors can be obtained from this factor. ${ }^{43,44}$ Typically, $k_{\$} A_{\&}$ can be established from electrode limiting current measurements or by fitting the reactant conversion over time to a plug flow reactor model. ${ }^{44,45}$ In the first case, $k_{\$} A \&$ is related to the limiting current at the porous electrode, $I 9$, by: 
$k_{\$} A_{\&}=\frac{I^{L}}{{ }_{z} F V e}$

where $c$ is the bulk concentration of the reactant, $F$ is the Faraday constant, $V \&$ is the volume of the electrode and $z$ is the electron stoichiometry. The limiting current, $I_{9}$, develops at the electrode when the rate of the electrochemical reaction is restricted by the supply/removal of ions to the electrode surface. The electrode current is coupled to the mass transport in the cell. These conditions are achieved when the electrode overpotential has increased sufficiently to move away from the open circuit potential, overcoming electron transfer control and mixed control. This ideal behaviour can be altered by deviations from steady state, uncompensated ohmic effects and current distributions at large or porous electrodes. ${ }^{16,46} k \$ A_{\&}$ is usually given as a function of electrolyte mean linear electrolyte velocity but it can also acquire an economical significance when related to $\Delta P$. An empirical power law relationship can be established between the two terms: ${ }^{19}$

$k \$ A \&=p \Delta P^{@}$

where $p$ and $q$ are empirical constants.

\section{Materials and Methods}

Flowing electrolyte

Pressure drop measurements were performed using a typical electrolyte for the positive halfcell of Ce-based redox flow batteries, except in the case of the felt material, where deionised water was used instead. The solution had a composition of $0.8 \mathrm{~mol} \mathrm{dm}^{-3} \mathrm{Ce}(\mathrm{III})$ methanesulfonate in 
$4.0 \mathrm{~mol} \mathrm{dm}{ }^{-3}$ methanesulfonic acid (MSA). A suspension of hydrated cerium carbonate (99\% purity, Treibacher Industrie AG, Austria) was prepared in deionised water (conductivity of 4.5 $\mu \mathrm{S} \mathrm{cm}^{-1}$ ) and neutralised under constant stirring with the stoichiometric volume of methanesulfonic acid (99\% purity, Acros Organics, USA), followed by the addition of 4.0 mol $\mathrm{dm}^{-3}$ of the same acid. The concentration of $\mathrm{Ce}(\mathrm{III})$ methanesulfonate was verified by volumetric titration against Fe(II). ${ }^{47}$ The viscosity of the solution was measured with an ASTM calibrated Oswald viscometer (Poulten Selfe \& Lee Ltd, UK). The temperature was controlled to $\pm 0.5{ }^{\circ} \mathrm{C}$ by immersion in a thermostatic bath, allowing 5 minutes for equilibration. The Ce(III) solution had a density, $\rho$, of $1.37 \mathrm{~g} \mathrm{~cm}^{-3}$, a dynamic viscosity, $\mu$, of $5.31 \times 10^{-2} \mathrm{~g} \mathrm{~cm}^{-1} \mathrm{~s}^{-}$ ${ }^{1}$, a kinematic viscosity, $v$, of $3.9 \times 10^{-2} \mathrm{~cm}^{2} \mathrm{~s}^{-1}$ and a Schmidt number, $S c$, of 45,348 at $25^{\circ} \mathrm{C}$.

\section{Characteristics of the electrodes}

The macroscopic appearance of the evaluated Pt/Ti porous electrodes and the inert 'turbulence promoter' (ITP) employed along the Pt/Ti planar electrode is shown in Figure 1. Their dimensions, equivalent hydraulic diameter and volumetric porosity are given in Table 1 . Pt/Ti plate and Pt/Ti mesh electrodes were sourced externally, while Pt/Ti felt and Pt/Ti micromesh electrodes were electroplated with platinum in a flow cell using alkaline plating solutions. A detailed description of their manufacture has been provided in previous work. ${ }^{48,49}$

The Pt/Ti plate and Pt/Ti mesh electrodes were obtained from Magneto Special Anodes BV (The Netherlands). The platinum coating of the Pt/Ti plate and Pt/Ti mesh had an approximate thickness of $3.5 \mu \mathrm{m}$. The Pt/Ti plate electrode had a thickness of $3.0 \mathrm{~mm}$ and it was platinum plated on one side only. Inert turbulence promoters (ITP) consisting of a stack of three $1.3 \mathrm{~mm}$ thick polypropylene meshes, Figure 1a, were placed in the rectangular flow channel of the electrode, in a similar fashion as in membrane-divided flow reactors. The internal aperture and 
pitch of the polypropylene mesh was $4.6 \mathrm{~mm} \times 4.2 \mathrm{~mm}$ and $6.8 \mathrm{~mm} \times 8.0 \mathrm{~mm}$, respectively. The Pt/Ti mesh electrode, shown in Figure 1b, was formed by a stack of three pieces (each 2.4 mm thick) of expanded titanium mesh spot-welded to a $3.0 \mathrm{~mm}$ titanium plate. The internal aperture of this mesh was $3.2 \mathrm{~mm} \times 7.1 \mathrm{~mm}$ with a pitch of $6.8 \mathrm{~mm} \times 10.1 \mathrm{~mm}$.

The Pt/Ti micromesh electrode, shown in Figure 1c, was constructed by spot-welding a stack of sixteen individual pieces of $170 \mu \mathrm{m}$ thick titanium micromesh (Dexmet Co., USA) to a solid $0.9 \mathrm{~mm}$ thick titanium plate. The size of these pieces was $60 \mathrm{~mm} \times 25 \mathrm{~mm}$. As a way to provide a space for the flow between the flat (non-expanded) micromesh, $60 \mathrm{~mm} \times 5 \mathrm{~mm}$ strips were interspersed between them at the edges of the electrode. The internal aperture of the micromesh was $375 \mu \mathrm{m} \times 625 \mu \mathrm{m}$ and the pitch $670 \mu \mathrm{m} \times 1000 \mu \mathrm{m}$. The average volumetric Pt loading of this electrode was $6.4 \mathrm{mg} \mathrm{cm}^{-3} .{ }^{16} \mathrm{The} \mathrm{Pt} / \mathrm{Ti}$ felt electrode, shown in Figure 1d, was a continuous, 3.6 mm thick body of sintered titanium fibres (NV Bekaert SA, Belgium), spot-welded to a 0.9 mm titanium current collector. The cross-sections of the individual titanium fibres were rectangular-like, with an average side length of $42.3 \pm 4.4 \mu \mathrm{m}$. The Pt/Ti felt electrode underwent three electroplating steps, ${ }^{48}$ and the resulting electrodes were termed: Pt/Ti felt 'A', Pt/Ti felt ' $\mathrm{B}$ ' and Pt/Ti felt ' $\mathrm{C}$ ', which had average volumetric Pt loadings of $4.6 \mathrm{mg} \mathrm{cm}^{-3}, 9.3 \mathrm{mg} \mathrm{cm}^{-3}$, and $18.3 \mathrm{mg} \mathrm{cm}^{-3}$, respectively. ${ }^{16}$ Computer tomography (CT) imaging revealed that Pt was deposited in a zone approximately $200 \mu \mathrm{m}$ deep from the outer surface of the felt electrodes, in a plane opposite to the current collector. ${ }^{48}$ As seen in Figure 1d, this Pt coated zone was still porous and represented no more than $5.6 \%$ of the cross-sectional area of the electrode; see Table 1. Given the small volume of Pt, it can be safely assumed that the porosity and pressure drop of the plated materials were not significantly altered compared to the bare Ti felt at which the pressure drop measurements were performed. 


\section{Measurement of pressure drop}

The hydraulic pressure drop characteristics of the different porous electrodes were determined using the rectangular channel flow cell in Figure 2a. As seen in Figure 2b, pressure taps passed through drilled openings in the electrode frame into the flow channel at symmetrical positions, $10.0 \mathrm{~mm}$ below and above the porous electrodes (vertical axis). This configuration permits to measure the pressure drop through the porous materials, avoiding that taking place over the flow cell manifolds. In order to avoid external flow bypass, silicone rubber gaskets were placed in the space between the Pt/Ti plate + ITP and Pt/Ti mesh electrodes and the walls of the acrylic flow frame $(<1.0 \mathrm{~mm})$. In the case of the Pt/Ti micromesh and felt, this $(<0.5 \mathrm{~mm})$ space was filled with silicone sealant. Pressure drop measurements were performed with a Digitron 2023P manometer (Sifam Instruments Ltd, UK) using the flow circuit shown in Figure 3. The pressure taps were connected to the manometer via two polypropylene tubes of $2.0 \mathrm{~mm}$ internal diameter and a Masterflex ${ }^{\mathrm{O}} \mathrm{L} / \mathrm{S}^{\mathrm{O}}$ (Cole-Parmer Co, USA) peristaltic pump was used to circulate the electrolyte. Flow pulsation was removed by connecting a pulse dampener to the pump outlet. The temperature of the fluid was maintained at $25.0 \pm 0.5^{\circ} \mathrm{C}$ with the aid of a thermostatic water bath (Grant Instruments Ltd, UK).

The pressure drop through the Pt/Ti plate + ITP, Pt/Ti mesh and Pt/Ti micromesh was measured using the positive electrolyte for cerium-based RFBs. However, the pressure drop at the Pt/Ti felt exceeded the operational range of the peristaltic pump and was measured instead using deionised water, which has a dynamic viscosity of $8.9 \times 10^{-3} \mathrm{~g} \mathrm{~cm}^{-1} \mathrm{~s}^{-1}$. (The peristaltic pump head $\mathrm{P} / \mathrm{S}^{\mathrm{O}}$ Easy-load ${ }^{\mathrm{O}}$ suffers a decrease in pressure suction capacity over $58.8 \mathrm{kPa}^{50}$ ) These values permitted to calculate the permeability of the Pt/Ti felt, while the theoretical pressure drop with the battery cerium electrolyte was estimated by considering its dynamic viscosity. 
The extrapolated pressure drop values are reliable, as solutions of inorganic acids and low molecular weight compounds (non-polymers) are Newtonian fluids. ${ }^{51}$

\section{Determination of electrochemical performance}

A detailed description of the experimental procedure for the determination of the volumetric mass transport coefficient $k \$ A$ \& has been provided in a previous work. ${ }^{16}$ The value of $k \$ A$ \& for each electrode was determined as a function of $v$ by the limiting current technique, which relates the electrical current under convection-diffusion reaction control to the mass transport coefficient of the electroactive species dissolved in the flowing electrolyte and the electrode surface area. The current for the reduction of $0.1 \mathrm{~mol} \mathrm{dm}^{-3} \mathrm{Ce}(\mathrm{IV})$ was measured by chronoamperometry at a potential of $+0.2 \mathrm{~V}$ vs. $\mathrm{Hg} \mid \mathrm{Hg}_{2} \mathrm{SO}_{4 \text { (satd) }}$ for increasing electrolyte flow rate steps (applied every 15 or 30 seconds) using an Autolab potentiostat connected to a $20 \mathrm{~A}$ booster (Metrohm AG, The Netherlands).

\section{Results and Discussion}

Hydraulic pressure drop through porous Pt/Ti electrodes

The pressure drop produced by the electrode materials as a function of mean linear electrolyte velocity and Reynolds number, respectively, is presented in Figures 4a and 4b. A wide range of pressure drop values are obtained over the diverse structures. $\Delta P$ increases as a function of the mean linear flow rate in each of the $6.0 \mathrm{~cm}$ long electrodes. The Pt/Ti felt electrode yields the highest $\Delta P$ (max. $259.5 \mathrm{kPa}$ at $12 \mathrm{~cm} \mathrm{~s}^{-1}$ ), followed by the Pt/Ti micromesh (max. $28.8 \mathrm{kPa}$ at $14 \mathrm{~cm} \mathrm{~s}^{-1}$ ). The polypropylene ITP within the Pt/Ti planar electrode flow channel displays $\Delta P$ values two orders of magnitude lower than the felt (max. $1.03 \mathrm{kPa}$ at $17 \mathrm{~cm} \mathrm{~s}^{-1}$ ). The lowest $\Delta P$ is observed at the relatively open Pt/Ti mesh (max. 264.4 Pa at $8 \mathrm{~cm} \mathrm{~s}^{-1}$ ). As expected, materials with small size pore openings and high surface area offer more resistance to fluid flow. 
These findings can be contrasted to the pressure drop produced over other porous materials, although Reynolds number and normalized parameters such as Darcy’s friction factor and permeability are more appropriate for these comparisons, vide infra. As an example, the pressure drop through a $4.0 \mathrm{~cm}$ long rectangular channel containing an uncompressed $20 \mathrm{ppi} \mathrm{Al}$ is intermediate between the Pt/Ti mesh and Pt/Ti plate + IPT electrodes, ${ }^{52}$ see Figure 4a, while $10 \mathrm{ppi}$ and $40 \mathrm{ppi} \mathrm{Al}$ foam can reach up to $420 \mathrm{~Pa}$ and $1.42 \mathrm{kPa}$ at a mean linear electrolyte flow velocity of $20 \mathrm{~cm} \mathrm{~s}^{-1}$ of water. ${ }^{52}$ The pressure drop through inert mesh spacers (3.5 cm long) for desalination reactors has been close to $2.0 \mathrm{kPa}$ at a mean linear electrolyte flow velocity of $30 \mathrm{~cm} \mathrm{~s}^{-1}$ of the same fluid. ${ }^{53}$

The combined pressure drop over electrode materials and electrolyte manifolds in electrochemical flow cells has also been considered. For instance, the FM01-LC reactor containing inert turbulence promoters type ' $\mathrm{D}$ ' and a planar electrode developed pressure drops from $1.0 \mathrm{kPa}$ at $5 \mathrm{~cm} \mathrm{~s}^{-1}$ to $8.3 \mathrm{kPa}$ at $16 \mathrm{~cm} \mathrm{~s}^{-1}$ when using a $1.0 \mathrm{~mol} \mathrm{dm}{ }^{-3} \mathrm{Na}_{2} \mathrm{CO}_{3}$ based electrolyte; ${ }^{20}$ see Figure 4a. The overall pressure drop in an ElectroSynCell ${ }^{\grave{~}}$ industrial flow reactor, equipped with 60 ppi nickel foam electrodes, was $14.6 \mathrm{kPa}$ at a maximum volumetric flow rate of $133.3 \mathrm{~cm}^{3} \mathrm{~s}^{-1}$ of $0.5 \mathrm{~mol} \mathrm{dm}{ }^{-3} \mathrm{NaOH}$ solution, ${ }^{54}$ of which approximately $1.7 \mathrm{kPa}$ appeared over the foam. In a cell containing a carbon felt electrode (length $12 \mathrm{~cm}$ ) with a compression ratio of $80 \%$ the pressure drop reached $21.7 \mathrm{kPa}$ at a flow velocity of $20 \mathrm{~cm} \mathrm{~s}^{-1}$ using $0.5 \mathrm{~mol} \mathrm{dm}{ }^{-3} \mathrm{Na}_{2} \mathrm{SO}_{4}$ as fluid. ${ }^{40}$ These data show that low pressure drop is common in reactors using planar or expanded metal electrodes.

Regarding the pressure drop in RFB cells and stacks, little experimental data is available. In a 10 unit cell $(L=108 \mathrm{~cm}, B=76 \mathrm{~cm}, S=1.0 \mathrm{~mm}$ ) stack for an utility scale brominepolysulfide 
RFB, the total pressure drop was $20.0 \mathrm{kPa}$ at an electrolyte mean linear (bromine) electrolyte flow velocity of $2 \mathrm{~cm} \mathrm{~s}^{-1}{ }^{22}$ This figure is relatively low due to the use of planar electrodes and a single turbulence promoter in each unit cell $(\varepsilon=0.73)$. Most of the literature on vanadium RFBs reports simulated, rather than experimental data. For instance, the approximate expected pressure drop over a single unit cell $(L=30 \mathrm{~cm}, B=50 \mathrm{~cm}, S=3.0 \mathrm{~mm})$ with a carbon felt electrode is $15.0 \mathrm{kPa}$ at a channel volumetric flow rate of $9.3 \mathrm{~cm}^{3} \mathrm{~s}^{-1}$ in the design by Ye et al. ${ }^{25}$

\section{Empirical correlation between pressure drop and Reynolds number}

As shown in Figure 5, a logarithmic-logarithmic plot can be used to establish the relationship between $\Delta P$ and the electrode channel $R e$ in the form of an empirical power law. The correlations are predominantly linear (with a squared correlation coefficient, $R^{2}>0.99$ ). $\Delta P$ through the Pt/Ti electrodes in this flow cell can be compared with that in the FM0l-LC reactor ${ }^{41}$ and a reactor by Colli et al., ${ }^{55}$ both as empty channels and with turbulence promoters. The empirical constants $d$ and $h$ for the Pt/Ti electrodes are given in Table 2, along the correlation values for compared cells. The values of $d$ are $<1$ in the compared reactors due to their larger $h$ slopes, which cause the intercept to acquire a negative value in the logarithmic plot. In the present work, the $h$ slopes indicate lesser increments of $\Delta P$ as a function of $R e$.

\section{Darcy's friction factor for porous Pt/Ti electrodes}

Darcy's friction factor, $f *$, of the porous electrodes was determined for the range of mean linear electrolyte flow rates using $\Delta P$ measurements according to the relationship:

$f^{*}=\underline{2 \Delta} L \rho \underline{P} v \underline{d} 2 \underline{e}$ 
where $d_{\&}$ is the hydraulic equivalent diameter of the flow channel, $L$ is the length of the porous electrode, $\rho$ is the electrolyte density and $v$ is the mean linear electrolyte velocity. As shown in Figure 6, the dimensionless friction factor values fall as the mean linear electrolyte flow rate increases due to the $v^{\mathrm{H}}$ term in the denominator of Equation (5). Figure 6a shows $f *$ as a function of $v$. The relatively closed $\mathrm{Pt} / \mathrm{Ti}$ felt material exhibits the highest impediment to flow $\left(f^{*}=\right.$ 2,903 to 78,157), followed by the more open Pt/Ti micromesh ( $f_{*}=173$ to 3,399). In this plot, $\mathrm{Pt} / \mathrm{Ti}$ mesh $\left(f_{*}=12.6\right.$ to 375$)$ and $\mathrm{Pt} / \mathrm{Ti}$ plate $+\operatorname{ITP}\left(f_{*}=5.6\right.$ to 151$)$ show a very similar relationship over the evaluated mean linear electrolyte flow rate. On the other hand, in Figure $6 \mathrm{~b}$, where $f *$ is a function of Reynolds number, the Pt/Ti plate + ITP clearly shows the lowest frictional loss in the flow cell.

These values can be compared to those observed at other three-dimensional electrodes in measurements carried out in the FM01-LC electrochemical flow reactor (converted from the Fanning friction factor) by Brown et al. ${ }^{19}$ The $f *$ values display an interesting apparent trend continuity for electrode materials with similar geometry and pore size openings, e.g. the metal 'stacked net'19 is comparable to the Pt/Ti micromesh and the 'expanded metal L'19 to the Pt/Ti mesh. The flow is less restricted at open metal mesh electrodes, independently of their electrochemical performance. Modified friction factors can also be used in the case of planar electrodes ${ }^{19}$ and roughened parallel plate electrodes. ${ }^{56}$ Friction factors have also been used to relate $\Delta P$ to the density and viscosity of the electrolyte in electrochemical flow cells. ${ }^{44}$

\section{Darcy's permeability of porous Pt/Ti electrodes}

The particular hydraulic perviousness of a porous materials is given by Darcy's permeability, $K$. This property is related to $\Delta P$ by: 
$K=\mathrm{JK} 9$

where $\mu$ is the dynamic viscosity of the fluid. Lower $K$ values indicate more resistance to fluid flow and higher $\Delta P$. The results shown in Figure 7 are in accordance with $f *$. In order of increasing average permeability: Pt/Ti felt $\left(K=1.31 \times 10^{-6} \mathrm{~cm}^{2}\right)$, Pt/Ti micromesh $\left(K=1.67 \times 10^{-}\right.$ $\left.{ }^{5} \mathrm{~cm}^{2}\right)$, Pt/Ti plate + ITP $\left(K=4.45 \times 10^{-4} \mathrm{~cm}^{2}\right)$, and Pt/Ti mesh $\left(K=7.10 \times 10^{-4} \mathrm{~cm}^{2}\right)$. The lowest permeability is shown by the electrode with smallest pore openings, i.e. the felt. Permeability values show little change over the evaluated mean linear electrolyte flow rate, except in the case of the Pt/Ti mesh, due to the difficulty of eliminating internal and external flow bypass in such an open material within a cell of relatively small dimensions. In contrast to $f *, K$ values of Pt/Ti mesh and Pt/Ti plate + ITP are well differentiated, either plotted against mean linear electrolyte velocity or Reynolds number; see Figure 7b. These results can be compared to the permeability of a '95-02' compressed aluminium foam for water $(\varepsilon=0.88)$ reported by Boomsa et al. ${ }^{52}$ and shown in Figure 7a. Another grade of aluminium foam $(\varepsilon=0.70)$ had a lower permeability of $1.2 \times 10^{-5} \mathrm{~cm}^{2} .{ }^{57}$ These structural analogues of $\mathrm{RVC}^{58}$ and nickel foam ${ }^{38}$ electrodes have a higher permeability than Pt/Ti micromesh. The type of carbon felt used in the vanadium RFB has a measured permeability of approximately $2.4 \times 10^{-6} \mathrm{~cm}^{2}(\varepsilon=0.96),{ }^{27}$ a value below that of the $\mathrm{Pt} / \mathrm{Ti}$ felt.

\section{The Ergun equation}

The pressure drop over a porous body can also be described as a function of mean linear flow rate by the Ergun equation: 
In this empirical correlation, $M$ represents the turbulence forces and $N$ represents the inertial forces causing the pressure drop. The first depends on the fluid density, surface area and porosity, and the second on the type of porous body and fluid viscosity. As shown in Figure 8, the relationship $\Delta P(L v)^{\mathrm{ST}} v s . v$ is linear for the $\mathrm{Pt} / \mathrm{Ti}$ micromesh at all mean linear flow velocities and for the Pt/Ti felt up to a mean linear flow velocity of $6 \mathrm{~cm} \mathrm{~s}^{-1}$. The values of the empirical constants $M$ and $N$ are given in Table 3. The Ergun plots for a carbon felt electrode $(\varepsilon=0.98)$ obtained by Gonzalez-García et al. ${ }^{59}$ in water are also presented in Figure 8. Different grades of felt/compartment thickness ratios (compression) are shown. The empirical constants values are also given in Table 3, being intermediate between the micromesh and the felt. In a cell with a relative small cross-sectional area open materials such as $\mathrm{Pt} / \mathrm{Ti}$ mesh and $\mathrm{Pt} / \mathrm{Ti}$ plate + ITP do not conform to the Ergun equation.

The Ergun constants can be used to estimate the surface area and tortuosity of highly porous electrodes, such as foams ${ }^{38}$ (a corrected relationship is given in ${ }^{39}$ ) or felts, ${ }^{59}$ and have also been related to $k_{\$} A_{\text {\& }}$ values. ${ }^{60}$ These and other semi-empirical expressions are not universal to all porous geometries, e.g., those based on packed-bed models require empirical modifications to describe the pressure drop through expanded metal.

\section{Electrochemical volumetric mass transport coefficient, $\boldsymbol{k}_{\boldsymbol{m}} \boldsymbol{A}_{\boldsymbol{e}}$}

The electrochemical performance of each electrode was determined from the limiting current, I9, for the reduction of $0.1 \mathrm{~mol} \mathrm{dm}^{-3}$ of $\mathrm{Ce}(\mathrm{IV})$ ions in a flow cell. As shown in Figure 9a, the limiting current increases with electrodes of large surface area and small pore size. In the case 
of the Pt/Ti felt electrodes, the content of electrocatalytic Pt on the surface of material has also a pronounced effect on increasing the limiting current. Pt/Ti felt A, Pt/Ti felt B and Pt/Ti felt C electrodes have an approximate Pt volumetric loading of $4.6 \mathrm{mg} \mathrm{cm}^{-3}, 9.3 \mathrm{mg} \mathrm{cm}^{-3}$, and 18.3 mg $\mathrm{cm}^{-3}$, respectively. ${ }^{16}$ Assuming steady state conditions and convectional diffusion reaction control, the volumetric mass transport coefficient $k_{\$} A_{\&}$ of the respective electrodes is calculated from $I_{9}$ in accordance to Equation (3). The log-log plot in Figure 9b presents the relation between $k \$ A$ \& and the mean linear flow velocity of the electrolyte. Values stretching over more than two orders of magnitude are produced by the different electrode structures. The electrode performance expressed as $k_{\$} A \&$ increases in the following sequence: plate (unrestricted channel) $<$ plate + ITP $<$ mesh $<$ felt A $<$ micromesh $<$ felt B $<$ felt C. Micromesh and felt electrodes will significantly increase the fractional conversion rate in a given flow cell or RFB in comparison to mesh or planar electrodes. A detailed discussion of these results and empirical relationships describing $k_{\$} A \& v s . v$ can be found in a related work. ${ }^{16}$

\section{Empirical correlation involving $\boldsymbol{k}_{\boldsymbol{m}} \boldsymbol{A} \boldsymbol{e}, \Delta \boldsymbol{P}$ and Reynolds number}

The electrode performance factor $k_{\$} A$ \& at a given electrolyte mean linear velocity can be related to $\Delta P$ to give a description of to the pump demands of different three-dimensional electrodes. This relationship has economic significance and implications to the design of an electrochemical flow cell or flow reactor. Figure 10 shows a logarithmic-logarithmic plot were the $k_{\$} A$ \& values of the different $\mathrm{Pt} / \mathrm{Ti}$ electrodes are plotted against their corresponding $\Delta P$ for a given mean linear electrolyte velocity, which are shown in Figure 4a. The empirical constants $p$ and $q$ describing each electrode are presented in Table 4. The constant $p$ has higher values for electrodes with greater $k_{\$} A \&$, while the $q$ exponent appears to be smaller at those producing high $\Delta P$. Materials with large surface area (related to $A_{\&}$ ) and smaller pore sizes enhance mixing 
and turbulence, producing both higher $k \$$ and $\Delta P$. Permeable mesh electrodes and planar electrodes + ITP have a limited surface area, which results in relatively low $\Delta P$ at the cost of poor $k \$ A$ \& values and the associated low rate of electrochemical fractional conversion.

Figure 10 also shows the $k_{\$} A \& v s . \Delta P$ relationship for other metallic porous electrodes, as measured in the FM01-LC reactor for the reduction of $5.0 \times 10^{-3} \mathrm{~mol} \mathrm{dm}^{-3}$ ferricyanide in a 1.0 mol $\mathrm{dm}^{-3} \mathrm{KOH}$ supporting solution. ${ }^{19}$ The constants in Table 4 can be contrasted to those observed in the FM01-LC reactor. At these structures, $p$ ranged from $7.6 \times 10^{-4}$ to $7.2 \times 10^{-3}$ and $q$ varied from 0.22 to 0.64 . The values of $\Delta P$ seem consistent for electrode geometries, but $k \$ A \&$ is higher for in the FM01-LC reactor due to the low viscosity of the electrolyte. In comparison, the electrolyte used in this study contains $0.8 \mathrm{~mol} \mathrm{dm}^{-3}$ of cerium methanesulfonate in $4.0 \mathrm{~mol}$ $\mathrm{dm}^{-3}$ methanesulfonic acid ( $\left.S c=45,348\right)$, hence the lower contribution of $k \$$ to the performance factor. Using semi-empirical expressions, the pressure drop through other porous electrodes has alternatively been expressed as a function of $A_{\&}{ }^{61}$ and $k \$,{ }^{60}$ when one of the terms is accurately known.

Returning to Figure 10, permeable three dimensional electrodes, such as $\mathrm{Pt} / \mathrm{Ti}$ mesh and Pt/Ti plate + ITP, yield low pressure drop and require less pumping power. However, the relatively low $k \$ A$ \& of the Pt/Ti mesh results in high cell overpotentials in a RFB and implies relatively low conversion per pass. ${ }^{16}$ Furthermore, in the Pt/Ti plate + ITP $k \$ A \&$ is low enough to induce concentration polarisation and significant oxygen evolution with associated low voltage and current efficiencies in a Zn-Ce RFB. ${ }^{16}$ On the other hand, the less permeable Pt/Ti micromesh presents $k_{\$} A$ \& values nearly an order of magnitude superior to the Pt/Ti mesh. The Pt/Ti felt has the smallest pore openings and therefore the pressure drop experienced by the electrolyte is the 
highest, although still below a manageable 1 bar $(100 \mathrm{kPa})$ in this cell. In this material, the degree of Pt coverage gives different $k_{\$} A_{\&}$ values. The electrode performance of Pt/Ti felt A and $\mathrm{Pt} / \mathrm{Ti}$ felt $\mathrm{B}$ offers no advantage over the micromesh, while the Pt/Ti felt $\mathrm{C}$ (highest Pt content) shows a superior performance to that of the micromesh at any given electrolyte mean linear electrolyte flow rate over $1 \mathrm{~cm} \mathrm{~s}^{-1}(22.9 \mathrm{kPa})$, although at the cost of higher pressure drop in the cell. A Pt/Ti felt with $100 \%$ Pt coverage can be expected to improve these results. In a complementary work, ${ }^{16}$ a Zn-Ce RFB afforded cell potentials of $1.2 \mathrm{~V}$ and $1.7 \mathrm{~V}$ when using the Pt/Ti micromesh and Pt/Ti felt $\mathrm{C}$ as positive electrodes, respectively, at a discharge current density of $100 \mathrm{~mA} \mathrm{~cm}^{-2}$.

The $\Delta P$ over electrode materials such as the micromesh and felt can be reduced by shortening their effective flow path length, which can be achieved by adopting a flow-across configuration (rather than the present flow-by) or electrolyte feeding through interdigitated flow fields machined into the bipolar electrodes. For instance, carbon felt electrodes in such configuration produce a pressure drop in the range of $500 \mathrm{~Pa}$ at $R e=220$ in a $80 \mathrm{~mm} \times 51 \mathrm{~mm}$ rectangular channel, ${ }^{62}$ which is comparable to the Pt/Ti mesh electrode; see Figure 4b. The use of thinner, fully coated Pt/Ti felt would exhibit high electrode performance and comparatively lower pressure drop.

\section{Conclusions}

This work demonstrates the characterization of porous electrodes used in RFBs and other electrochemical flow reactors. It is shown that normalized, scalable factors can be calculated from pressure drop measurements as a function of mean linear electrolyte velocity. Such factors are important, since they enable the comparison of the hydraulic properties of different materials and cell designs at different scales. Commercially available porous electrode materials (plate, 
mesh, micromesh, foam, felt, etc.) and turbulence promoters display a wide range or permeability values, implying different pressure drop, pumping power demand and overall energy efficiency. Moreover, the hydraulic properties of porous electrodes can be related to their electrochemical performance in a quantitative manner. In general, electrodes yielding high $k_{\$} A \&$ values have, naturally, larger surface areas and smaller pore sizes which tend to increase the pressure drop in the flowing electrolyte at a given mean linear electrolyte flow rate or Reynolds number. Such behaviour can be described and predicted by empirical power laws. This has been illustrated by the Pt/Ti porous electrodes for Ce-based RFBs here presented. In this case, Pt/Ti expanded metal mesh displays an average permeability of $7.10 \times 10^{-4} \mathrm{~cm}^{2}$, followed by the Pt/Ti plate + an inert turbulence promoter at $4.45 \times 10^{-4} \mathrm{~cm}^{2}$ and the $\mathrm{Pt} / \mathrm{Ti}$ micromesh at $1.67 \times 10^{-5} \mathrm{~cm}^{2}$. The permeability of Pt/Ti felt is nearly two orders of magnitude lower than that of the mesh electrode, $1.31 \times 10^{-6} \mathrm{~cm}^{2}$. Despite the large variation in the permeability of electrodes, pumping losses in well-designed RFB stacks with felt structures are generally manageable and high electrochemical performance is usually more important to achieve than low pressure drop. In any case, the high pressure drop through micromeshes, foams and felts can be reduced by implementing flow-across or interdigitated cell designs, when justifiable.

\section{Acknowledgements}

LFA gratefully acknowledges CONACYT and SEP scholarships from the Mexican government. Additional materials were provided by the Research Institute for Industry (RIfI) of the University of Southampton. All data supporting this study are openly available from the University of Southampton repository at http://doi.org/10.5258/SOTON/D0229. 


\section{Notation}

$A-\mathrm{z} \quad$ Electrode projected geometrical area $(A-\mathrm{z}=L B), \mathrm{cm}^{2}$

A\& Electrode area per unit electrode volume, $\mathrm{cm}^{-1}$

$A$. Cross-sectional of area the electrode $(A=B S), \mathrm{cm}^{2}$

$B \quad$ Breadth of rectangular flow channel, cm

c Reactant concentration, $\mathrm{mol} \mathrm{cm} \mathrm{cm}^{-3}$

$d \& \quad$ Equivalent diameter of a rectangular flow channel, $\mathrm{cm}$

$d \quad$ Empirical constant in equation (2), $\mathrm{Pa}$

$f_{*} \quad$ Darcy's friction factor , dimensionless

F $\quad$ Faraday constant, $\mathrm{C} \mathrm{mol}^{-1}$

$h \quad$ Empirical constant in equation (2)

I9 Limiting current due to convective-diffusion, A

$k \$ \quad$ Mass transfer coefficient, $\mathrm{cm} \mathrm{s}^{-1}$

$k_{\$} A \&$ Volumetric mass transfer coefficient, $\mathrm{s}^{-1}$

K Permeability, $\mathrm{cm}^{2}$

$L \quad$ Length of rectangular flow channel, $\mathrm{cm}$

$M \quad$ Ergun's empirical constant for turbulent forces, $\mathrm{Pa} \mathrm{s}^{2} \mathrm{~m}^{-3}$

$N \quad$ Ergun’s empirical constant for laminar flow, $\mathrm{Pa} \mathrm{s} \mathrm{m}^{-2}$

$p \quad$ Empirical constant in equation (4), $\mathrm{s}^{-1}$

$q \quad$ Empirical constant in equation (4)

$Q \backslash \quad$ Volumetric flow rate, $\mathrm{cm}^{3} \mathrm{~s}^{-1}$

Re Reynolds number, dimensionless

$S \quad$ Channel separation between electrode and membrane, $\mathrm{cm}$

$v \quad$ Mean linear flow velocity of electrolyte, $\mathrm{cm} \mathrm{s}^{-1}$

$V$ \& Overall volume of electrode, $\mathrm{cm}^{3}$ 
z Electron stoichiometry, dimensionless

\section{Greek letters}

$\gamma \quad$ Aspect ratio of flow channel, dimensionless

$\Delta P \quad$ Pressure drop, $\mathrm{Pa}$

$\varepsilon \quad$ Volumetric porosity, dimensionless

$v \quad$ Kinematic viscosity of the electrolyte, $\mathrm{cm}^{2} \mathrm{~s}^{-1}$

$\mu \quad$ Dynamic viscosity of the electrolyte, $\mathrm{g} \mathrm{cm}^{-1} \mathrm{~s}^{-1}$

$r \quad$ Fluid density, $\mathrm{g} \mathrm{cm}^{-3}$

Abbreviations

ITP Inert turbulence promoter

Pt/Ti Platinized titanium

RFB Redox flow battery

RVC Reticulated vitreous carbon

\section{References}

1. Arenas LF, Ponce de León C, Walsh FC. Electrochemical redox processes involving soluble cerium species. Electrochim Acta. 2016;205:226-247.

2. Harrison S, Théorêt A. The electrosynthesis of naphthoquinone and tetrahydroanthraquinone. J New Mat Electrochem Systems. 1999;2:1-9.

3. Company History. lonza.com. http://www.lonza.com/aboutlonza/companyprofile/company-history.aspx. Accessed August 31, 2017.

4. Ishii J, Kobayashi F, Uchida S, Sumiya M, Miki U. Basic study on decontamination of TRU waste with cerium-mediated electrolytic oxidation method. In: The 10th international conference. GLOBAL 2011. Toward and over the Fukushima Daiichi accident. Tokyo, 2011.

5. Varela JA, Oberg SG, Neustedter TM, Nelson N. Non-thermal organic waste destruction: Characterization of the CerOx system 4. Environmental Progress. 2001;20(4):261-271.

6. Walsh FC, Ponce de León C, Berlouis L, Nikiforidis G, Arenas-Martínez LF, Hodgson $\mathrm{D}$, Hall D. The development of Zn-Ce hybrid redox flow batteries for energy storage and their continuing challenges. ChemPlusChem. 2015;80(2):288-311. 
7. Fang B, Iwasa S, Wei Y, Arai T, Kumagai M. A study of the Ce(III)/Ce(IV) redox couple for redox flow battery application. Electrochim Acta. 2002;47(24):3971-3976.

8. Liu Y, Xia X, Liu H. Studies on cerium $\left(\mathrm{Ce}^{4+} / \mathrm{Ce}^{3+}\right)$-vanadium $\left(\mathrm{V}^{2+} / \mathrm{V}^{3+}\right)$ redox flow cell—cyclic voltammogram response of $\mathrm{Ce}^{4+} / \mathrm{Ce}^{3+}$ redox couple in $\mathrm{H}_{2} \mathrm{SO}_{4}$ solution. $J$ Power Sources. 2004;130(1-2):299-305.

9. $\quad$ Leung PK, Mohamed MR, Shah AA, Xu Q, Conde-Duran MB. A mixed acid based vanadium-cerium redox flow battery with a zero-gap serpentine architecture. J Power Sources. 2015;274:651-658.

10. Amstutz V, Toghill KE, Powlesland F, Vrubel H, Comninellis C, Hu X, Girault HH. Renewable hydrogen generation from a dual-circuit redox flow battery. Energy Environ Sci. 2014;7(7):2350-2358.

11. Na Z, Xu S, Yin D, Wang L. A cerium-lead redox flow battery system employing supporting electrolyte of methanesulfonic acid. J Power Sources. 2015;295:28-32.

12. Dewage HMH, Wu B, Tsoi A, Yufit V, Offer GJ, Brandon N. A novel regenerative hydrogen cerium fuel cell for energy storage applications. J Mater Chem A. 2015;3:9446-9450.

13. Tucker MC, Weiss A, Weber AZ. Cerium-hydrogen redox flow cell optimization. Meet Abstr. 2016;MA2016-01(3):379-379.

14. Zito R. Energy Storage: a New Approach. Hoboken (NJ): John Wiley \& Sons; 2010.

15. Arenas LF, Walsh FC, Ponce de León C. The importance of cell geometry and electrolyte properties to the cell potential of Zn-Ce hybrid flow batteries. $J$ Electrochem Soc. 2016;163(1):A5170-A5179.

16. Arenas LF, Ponce de León C, Walsh FC. Mass transport and active area of porous Pt/Ti electrodes for the $\mathrm{Zn}$-Ce redox flow battery determined from limiting current measurements. Electrochim Acta. 2016;221:154-166.

17. Hoberecht MA. Pumping Power Considerations in the Designs of NASA-Redox Flow Cells, TM-82598. NASA; 1981.

18. Hagedorn N, Hoberecht MA, Thaller LH. Redox Cell Stack Shunt Current, Pumping Power, and Cell Performance Tradeoffs, TM-82686. NASA; 1982.

19. Brown CJ, Walsh FC, Pletcher D. Mass transfer and pressure drop in a laboratory filterpress electrolyser. Trans IChemE. 1995;73(A):196-205.

20. Griffiths M, Ponce de León C, Walsh FC. Mass transport in the rectangular channel of a filter-press electrolyzer (the FM01-LC reactor). AIChE J. 2005;51(2):682-687.

21. Tsuda I, Kurokawa K, Nozaki K. Development of intermittent redox flow battery for PV system. In: Photovoltaic Energy Conversion 1994, Conference Record of the Twenty Fourth IEEE Photovoltaic Specialists Conference-1994. Hawaii, 1994: pp. 946-949. 
22. Ponce de León C, Whyte I, Reade GW, Male SE, Walsh FC. Mass transport and flow dispersion in the compartments of a modular 10 cell filter-press stack. Aust J Chem. 2008;61(10):797-804.

23. Ponce de León C, Reade GW, Whyte I, Male SE, Walsh FC. Characterization of the reaction environment in a filter-press redox flow reactor. Electrochim Acta. 2007;52(19):5815-5823.

24. Arenas LF, Ponce de León C, Walsh FC. Engineering aspects of the design, construction and performance of modular redox flow batteries for energy storage. $J$ Energy Storage. 2017;11:119-153.

25. Ye Q, Hu J, Cheng P, Ma Z. Design trade-offs among shunt current, pumping loss and compactness in the piping system of a multi-stack vanadium flow battery. $J$ Power Sources. 2015;296:352-364.

26. Tang A, Bao J, Skyllas-Kazacos M. Studies on pressure losses and flow rate optimization in vanadium redox flow battery. J Power Sources. 2014;248:154-162.

27. Averbukh M, Pozin A, Sukoriansky S. Electrolyte pumping optimization in already manufactured vanadium redox battery based on experimentally determined electrical and hydrodynamic losses. J Energy Eng. 2016:04016050.

28. Bromberger K, Kaunert J, Smolinka T. A model for all-vanadium redox flow batteries: Introducing electrode-compression effects on voltage losses and hydraulics. Energy Technology. 2014;2(1):64-76.

29. Xu Q, Zhao TS, Zhang C. Effects of SOC-dependent electrolyte viscosity on performance of vanadium redox flow batteries. Applied Energy. 2014;130:139-147.

30. Xiong B, Zhao J, Tseng KJ, Skyllas-Kazacos M, Lim TM, Zhang Y. Thermal hydraulic behavior and efficiency analysis of an all-vanadium redox flow battery. $J$ Power Sources. 2013;242:314-324.

31. Khazaeli A, Vatani A, Tahouni N, Panjeshahi MH. Numerical investigation and thermodynamic analysis of the effect of electrolyte flow rate on performance of all vanadium redox flow batteries. J Power Sources. 2015;293:599-612.

32. Kumar S, Jayanti S. Effect of flow field on the performance of an all-vanadium redox flow battery. J Power Sources. 2016;307:782-787.

33. Reed D, Thomsen E, Li B, Wang W, Nie Z, Koeppel B, Sprenkle V. Performance of a low cost interdigitated flow design on a $1 \mathrm{~kW}$ class all vanadium mixed acid redox flow battery. J Power Sources. 2016;306:24-31.

34. Chakrabarti MH, Mjalli FS, Al Nashef IM, Hashim MA, Hussain MA, Bahadori L, Low CTJ. Prospects of applying ionic liquids and deep eutectic solvents for renewable energy storage by means of redox flow batteries. Renew Sust Energ Rev. 2014;30(C):254-270. 
35. Ruggeri I, Arbizzani C, Soavi F. A novel concept of semi-solid, Li redox flow air $\left(\mathrm{O}_{2}\right)$ battery: a breakthrough towards high energy and power batteries. Electrochim Acta. 2016;206:291-300.

36. Regenesys utility scale energy storage. webarchive.nationalarchives.gov.uk. http://webarchive.nationalarchives.gov.uk/20070603164510/http://www.dti.gov.uk/ren ewables/publications/pdfs/kel00246moduletestprogramme.pdf. Published 2004. Accessed February 2, 2015.

37. Jyothi Latha T, Jayanti S. Hydrodynamic analysis of flow fields for redox flow battery applications. J Appl Electrochem. 2014;44(9):995-1006.

38. Langlois S, Coeuret F. Flow-through and flow-by porous electrodes of nickel foam. I. Material characterization. J Appl Electrochem. 1989;19(1):43-50.

39. Pletcher D, Whyte I, Walsh FC, Millington JP. Reticulated vitreous carbon cathodes for metal ion removal from process streams part I: Mass transport studies. J Appl Electrochem. 1991;21(8):659-666.

40. González-García J, Montiel V, Aldaz A, Conesa JA, Pérez JR, Codina G. Hydrodynamic behavior of a filter-press electrochemical reactor with carbon felt as a three-dimensional electrode. Ind Eng Chem Res. 1998;37(11):4501-4511.

41. Brown CJ, Pletcher D, Walsh FC, Hammond JK, Robinson D. Studies of spaceaveraged mass transport in the FM01-LC laboratory electrolyser. $J$ Appl Electrochem. 1993;23(1):38-43.

42. Pletcher D, Walsh FC. Three-dimensional electrodes. In: Gernders D, Weinberg N, eds. Electrochemistry for a Cleaner Environment. New York: The Electrosynthesis Company; 1992:51-100.

43. Langlois S, Coeuret F. Flow-through and flow-by porous electrodes of nickel foam Part III: theoretical electrode potential distribution in the flow-by configuration. $J$ Appl Electrochem. 1990;20(5):740-748.

44. Coeuret F, Storck A. Eléments De Génie Électrochimique. 2nd ed. Éditions TEC et DOC / Lavoisier; 1993.

45. Walsh FC. A First Course in Electrochemical Engineering. Romsey: The Electrochemical Consultancy; 1993.

46. Selman JR, Tobias CW. Mass-transfer measurements by the limiting current technique. In: Drew TB, Cokelet GR, Hoopes JW, Vermeulen T, eds. Advances in Chemical Engineering. 1978:211-318.

47. Patnaik P. Dean's Analytical Chemistry Handbook. McGraw Hill Professional; 2004.

48. Arenas LF, Ponce de León C, Boardman RP, Walsh FC. Electrodeposition of platinum on titanium felt in a rectangular channel flow cell. J Electrochem Soc. 2017;164(2):D57-D66. 
49. Arenas LF, Ponce de León C, Boardman RP, Walsh FC. Characterisation of platinum electrodeposits on a titanium micromesh stack in a rectangular channel flow cell. Electrochim Acta. 2017;247:994-1005.

50. Masterflex pump head - flow curves. http://www.peristaltic-pumptubing.com. Accessed December 4, 2016.

51. Chhabra RP, Richardson JF. Non-Newtonian Flow in the Process Industries: Fundamentals and Engineering Applications. Oxford: Butterworth-Heinemann; 1999.

52. Boomsma K, Poulikakos D. The effects of compression and pore size variations on the liquid flow characteristics in metal foams. J Hydroinform. 2002;124:263-272.

53. Dendukuri D, Karode SK, Kumar A. Flow visualization through spacer filled channels by computational fluid dynamics-II: Improved feed spacer designs. J Membrane Sci. 2005;249(1-2):41-49.

54. Montillet A, Comiti J, Legrand J. Application of metallic foams in electrochemical reactors of filter-press type part I: flow characterization. J Appl Electrochem. 1993;23(10):1045-1050.

55. Colli AN, Toelzer R, Bergmann MEH, Bisang JM. Mass-transfer studies in an electrochemical reactor with a small interelectrode gap. Electrochim Acta. 2013;100:78-84.

56. Rousar I, Cezner V. Mass Transfer Coefficients and Friction Coefficients for Rough Electrodes. Institution of Chemical Engineers Symposium Series; 1986.

57. Antohe BV, Lage JL, Price DC, Weber RM. Experimental determination of permeability and inertia coefficients of mechanically compressed aluminum porous matrices. J Fluids Eng. 1997;119(2):404-412.

58. Walsh FC, Arenas LF, Ponce de León C, Reade GW, Whyte I, Mellor BG. The continued development of reticulated vitreous carbon as a versatile electrode material: Structure, properties and applications. Electrochim Acta. 2016;215:566-591.

59. González-García J, Bonete P, Expósito E, Montiel V, Aldaz A, Torregrosa-Maciá R. Characterization of a carbon felt electrode: structural and physical properties. J Mater Chem. 1999;9(2):419-426.

60. Langlois S, Coeuret F. Flow-through and flow-by porous electrodes of nickel foam. II. Diffusion-convective mass transfer between the electrolyte and the foam. J Appl Electrochem. 1989;19(1):51-60.

61. Vilar EO, Coeuret F. Percolated porous electrodes composed of sintered metalhydrodynamics and mass transfer. Can J Chem Eng. 1998;76:41-50.

62. Jyothi Latha T, Jayanti S. Ex-situ experimental studies on serpentine flow field design for redox flow battery systems. J Power Sources. 2014;248:140-146. 


\section{Figures}

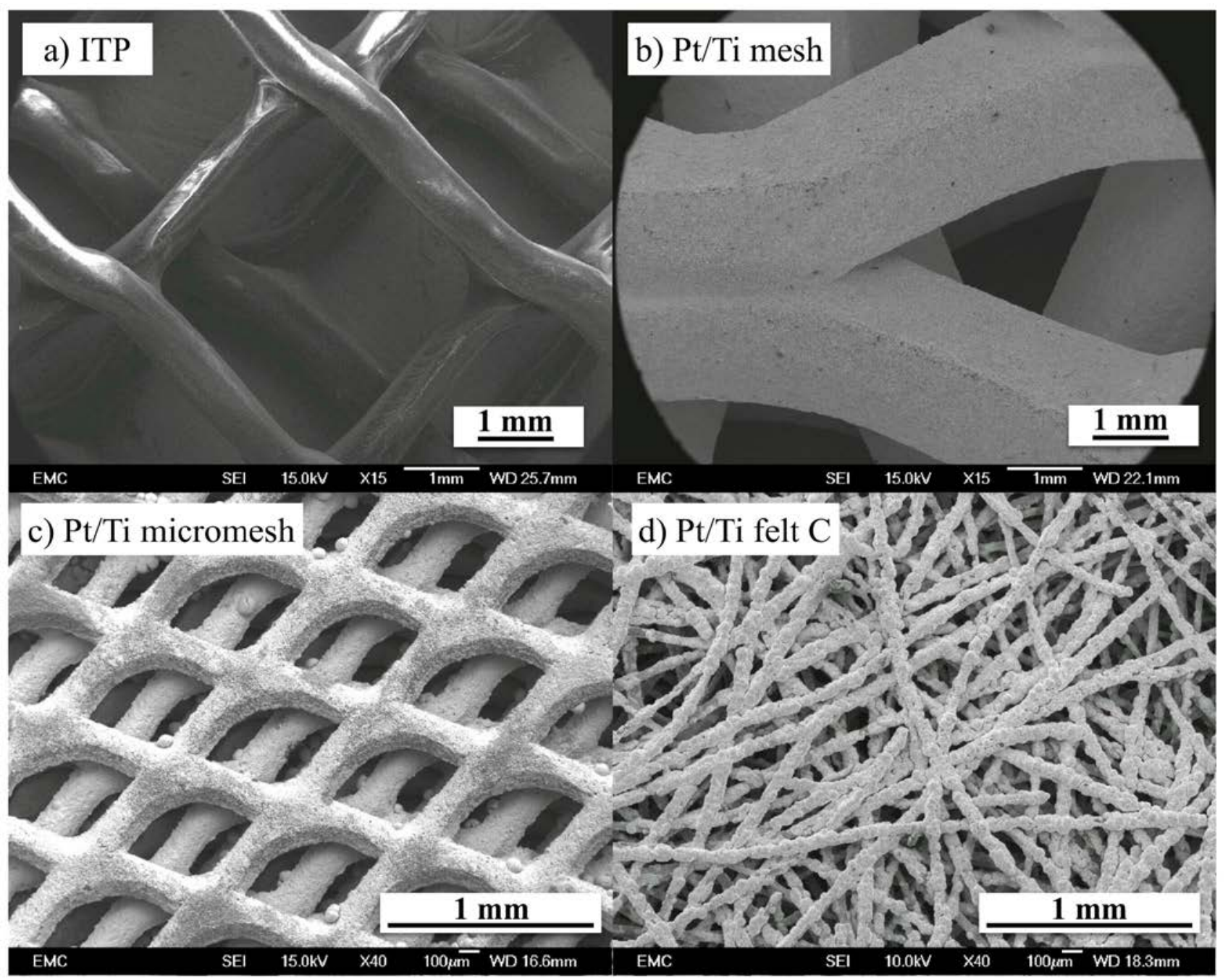

Figure 1. SEM images of the porous structures of the evaluated Pt/Ti electrodes: a) polypropylene inert turbulence promoter (ITP) used in the Pt/Ti plate + ITP electrode, b) Pt/Ti mesh, c) $\mathrm{Pt} / \mathrm{Ti}$ micromesh, d) Pt/Ti felt C. In these images, the overall direction of fluid flow through the materials is from left to right. 

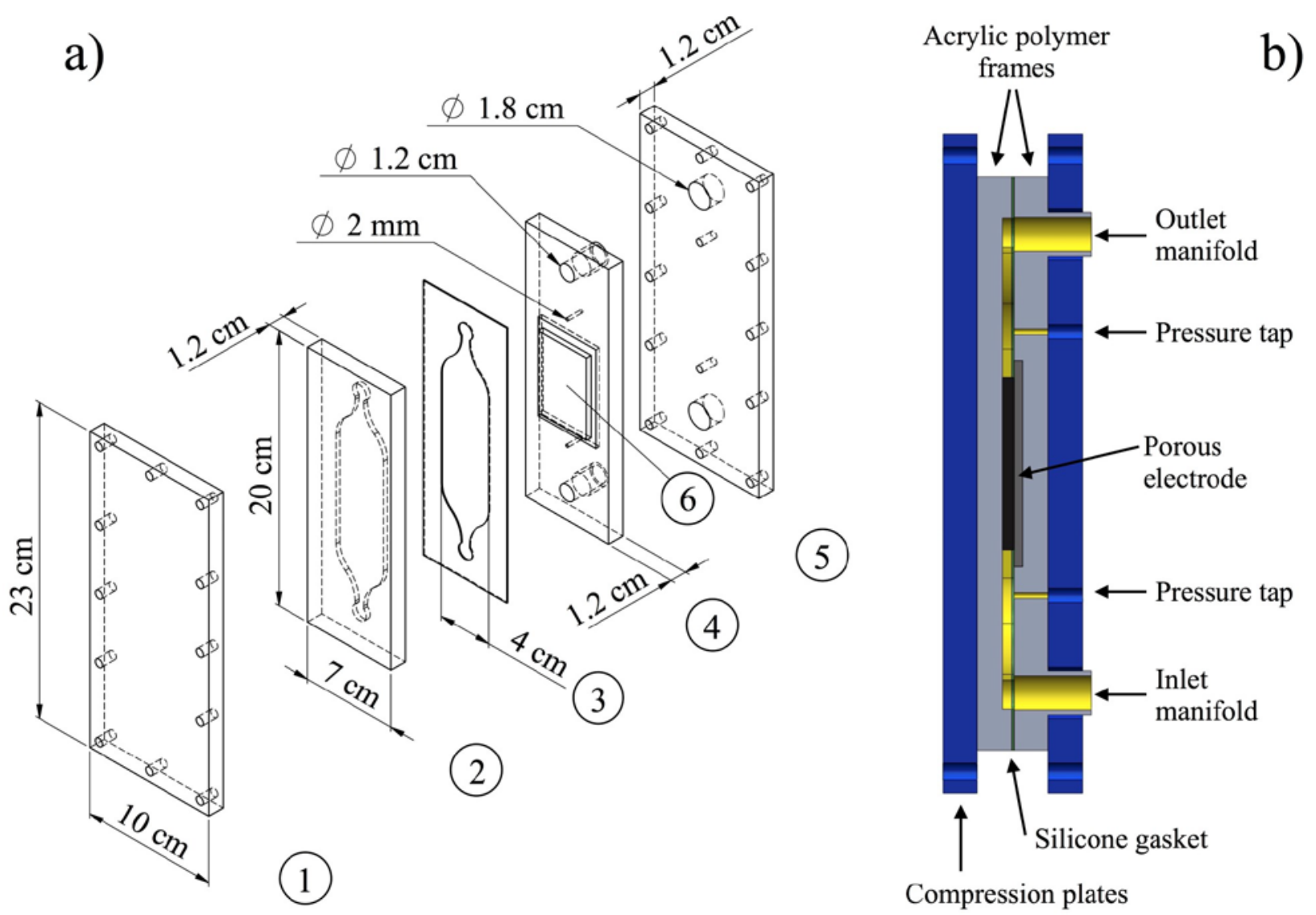

Figure 2. a) Filter-press type flow cell used in the measurement of pressure drop. b) cross-section of assembled flow cell. 1,5 compression plates; 2, acrylic polymer flow channel; 3, silicone gasket; 4, acrylic polymer electrode frame with manifolds and pressure taps; 6, porous electrode. Bolts are not shown. 


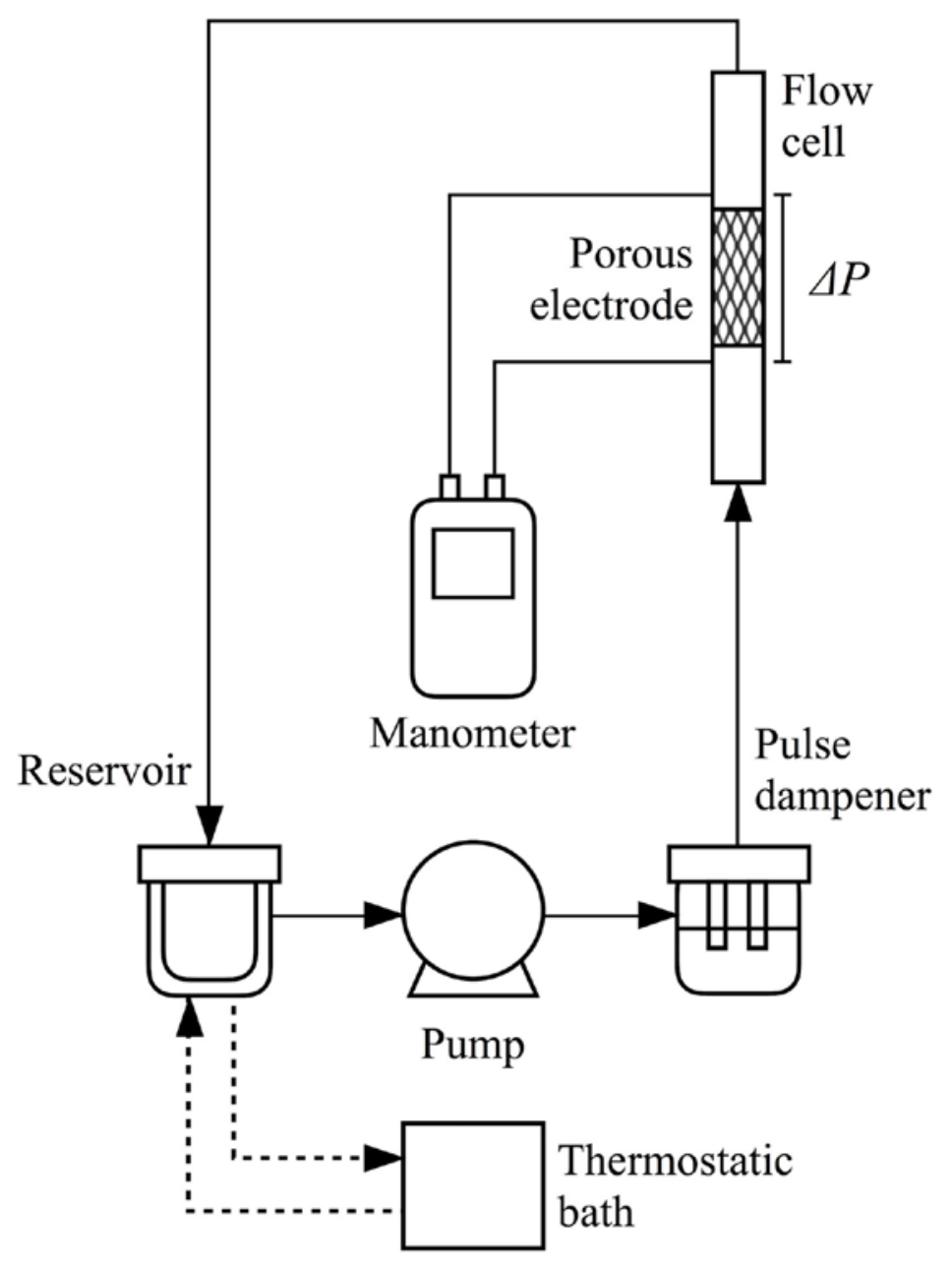

Figure 3. Recirculation system used in the pressure drop measurements. 

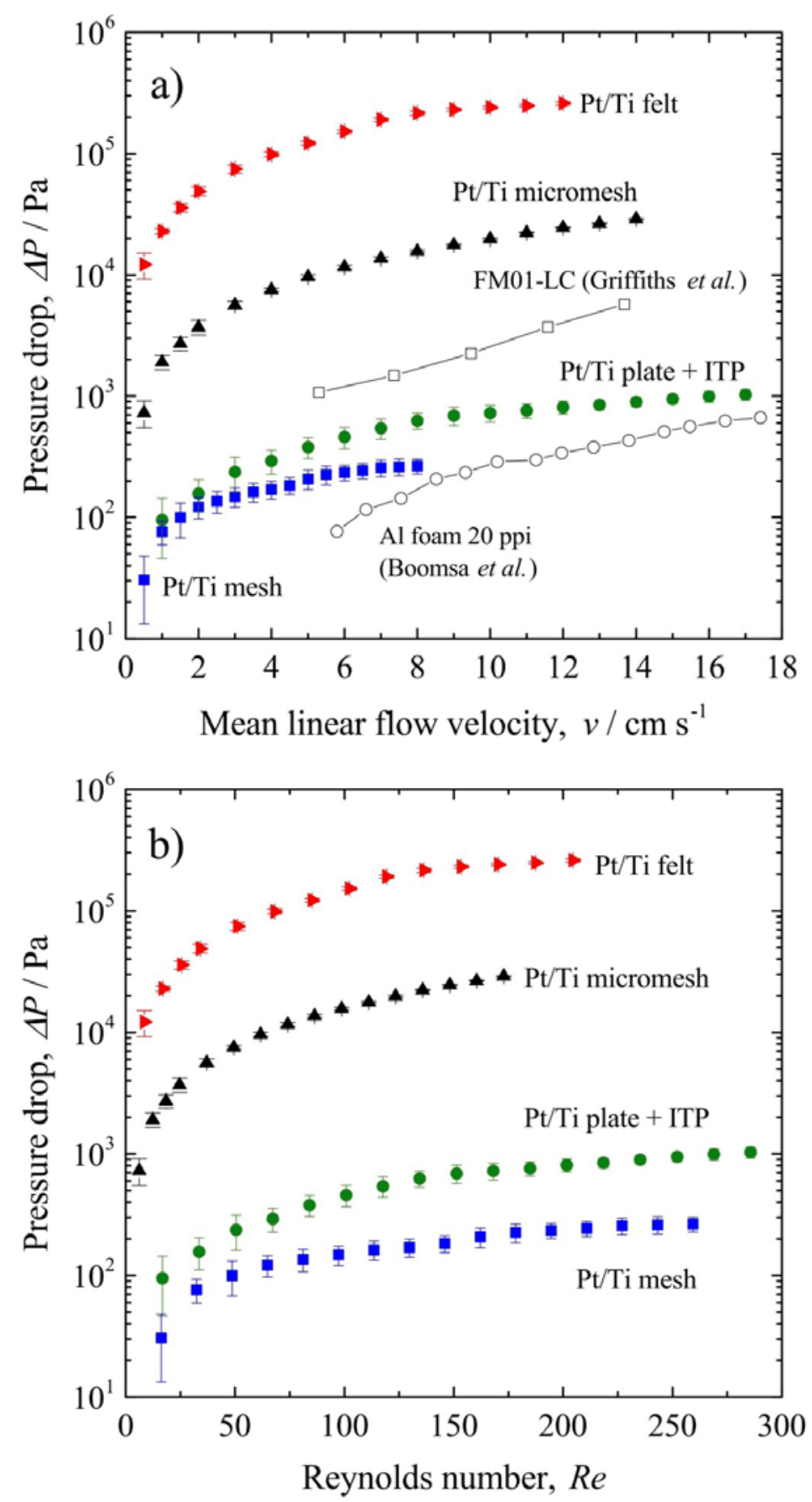

Figure 4. Pressure drop vs. a) electrolyte mean linear electrolyte velocity, b) Reynolds number for different electrode materials. Electrolyte composition: $0.8 \mathrm{~mol} \mathrm{dm}^{-3} \mathrm{Ce}(\mathrm{III})$ in $4 \mathrm{~mol} \mathrm{dm}^{-3}$ MSA at $25^{\circ} \mathrm{C}$. Results are compared to the FM01-LC reactor (promoter type ' $\left.\mathrm{D}^{\prime}\right)^{20}$ and an uncompressed 20 ppi Al foam by Boomsa et al. ${ }^{52}$ 


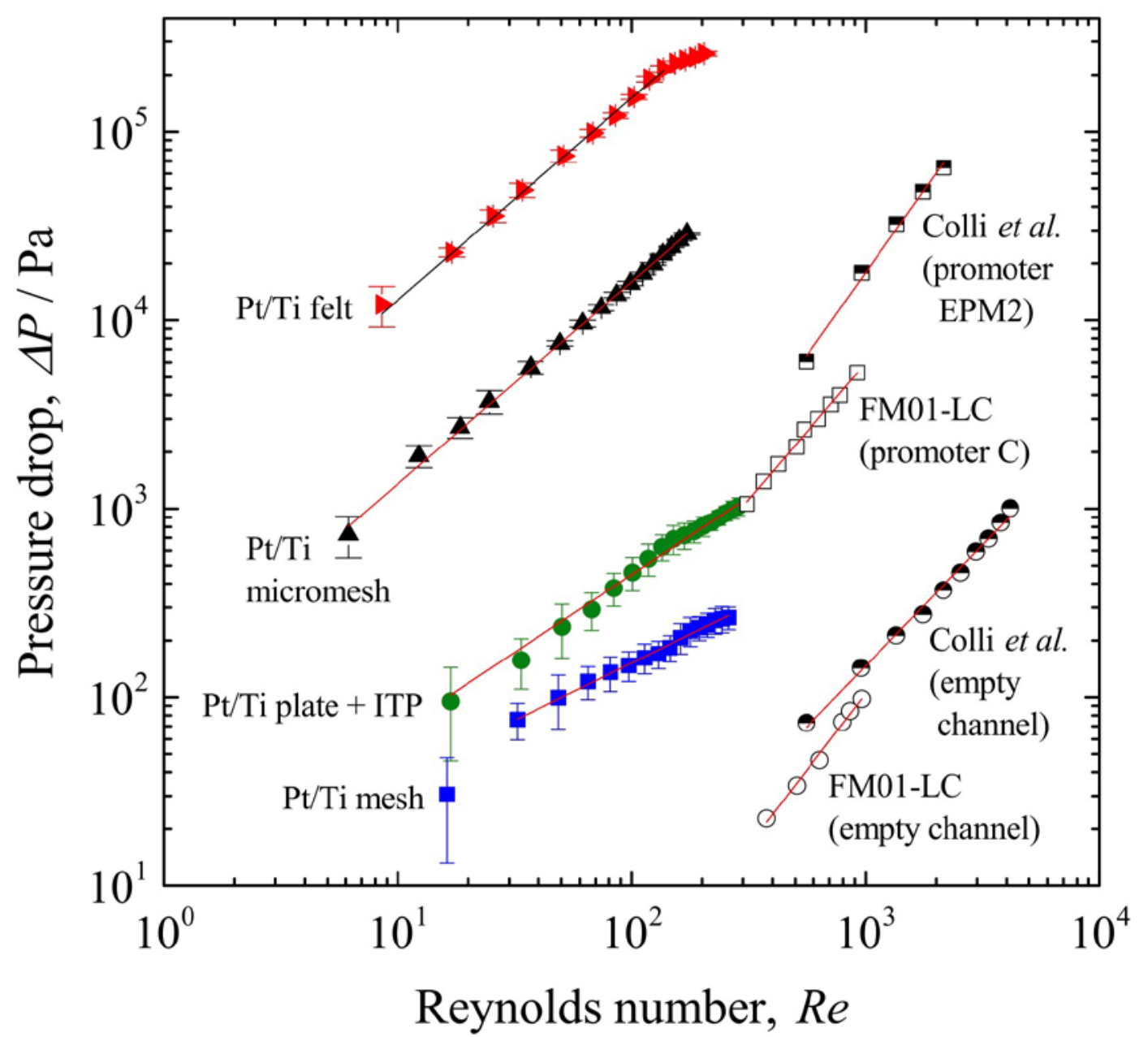

Figure 5. Pressure drop as a function of Reynolds number for different Pt/Ti electrode materials. Pressure drop measured in a solution containing $0.8 \mathrm{~mol} \mathrm{dm}^{-3} \mathrm{Ce}(\mathrm{III})$ in $4 \mathrm{~mol} \mathrm{dm}{ }^{-3} \mathrm{MSA}$ at $25^{\circ} \mathrm{C}$. Results are compared to the FM01-LC reactor (5.5 mm interelectrode gap) ${ }^{41}$ and the reactor by Colli et al. (1.0 mm interelectrode gap), ${ }^{55}$ both with empty flow channels and with turbulence promoters. 

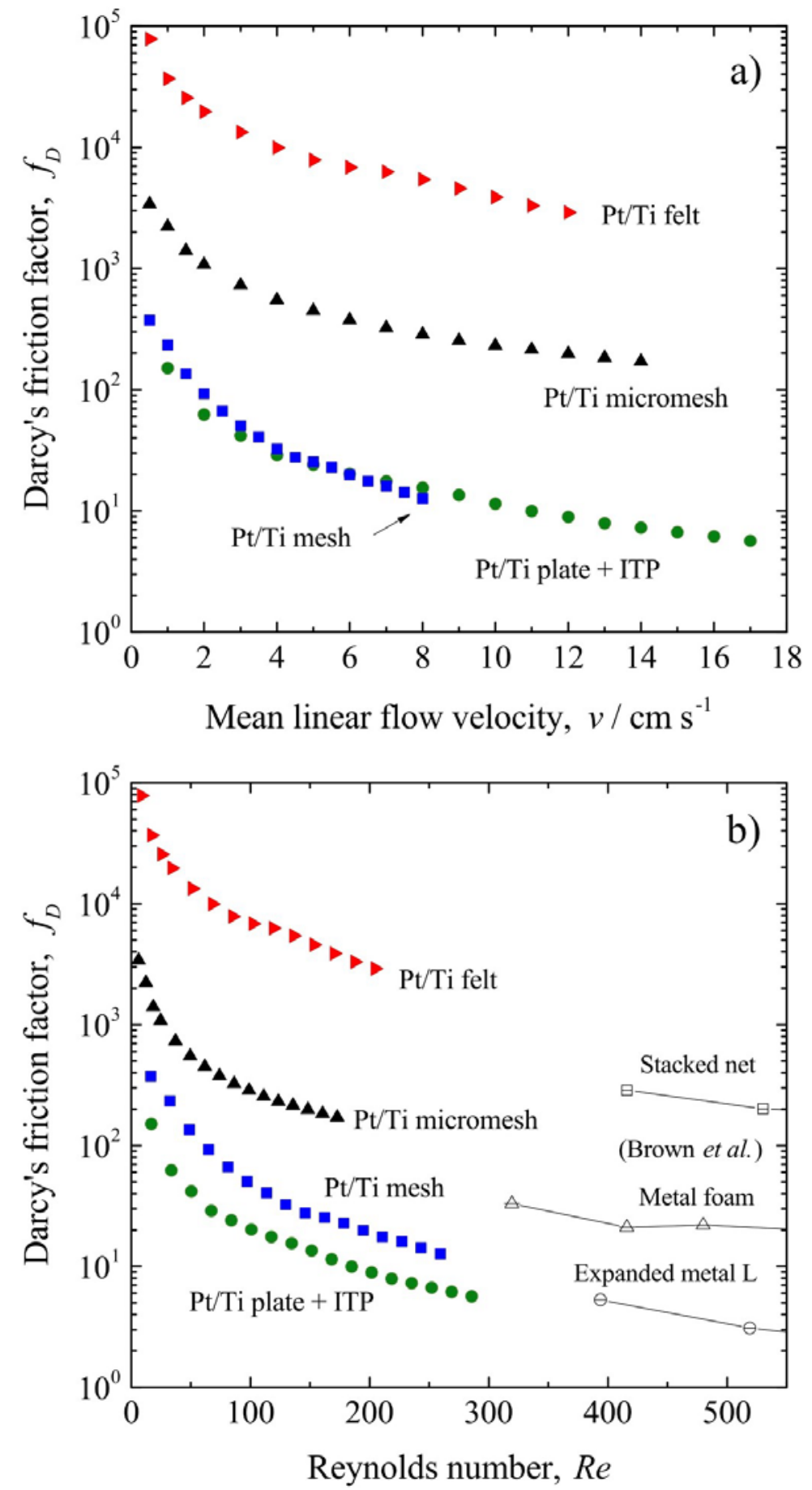

Figure 6. Darcy's friction factor vs. a) electrolyte mean linear electrolyte velocity, b) Reynolds number for different electrode materials. Electrolyte composition: $0.8 \mathrm{~mol} \mathrm{dm}^{-3} \mathrm{Ce}(\mathrm{III})$ in 4 mol dm ${ }^{-3} \mathrm{MSA}$ at $25{ }^{\circ} \mathrm{C}$. Results are compared to the friction factor of metal electrodes in the FM01-LC reactor, as given by Brown et al. ${ }^{19}$ 

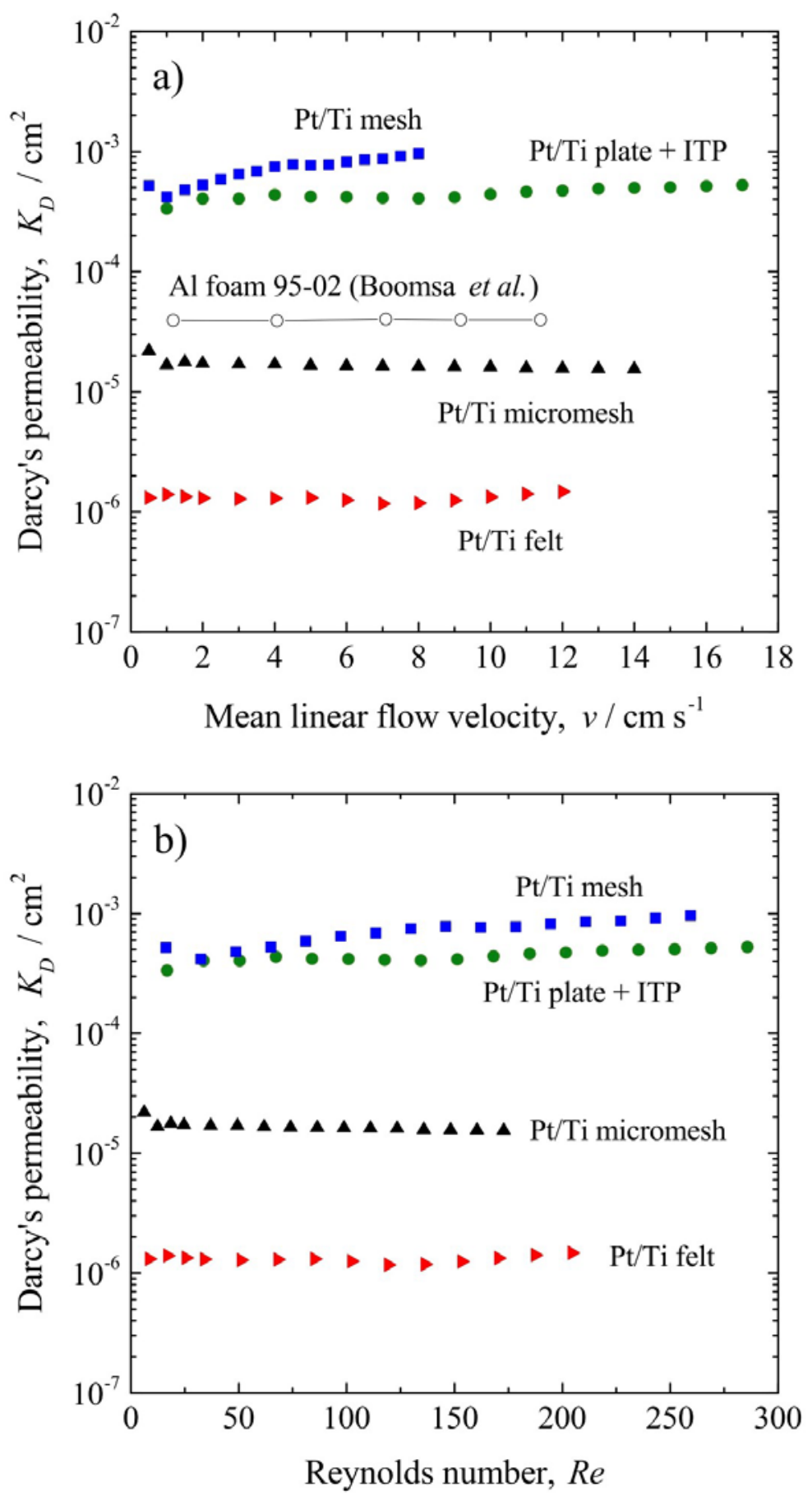

Figure 7. Darcy’s permeability vs. a) electrolyte mean linear electrolyte velocity, b) Reynolds number for different electrode materials. Electrolyte composition: $0.8 \mathrm{~mol} \mathrm{dm}{ }^{-3} \mathrm{Ce}(\mathrm{III})$ in 4 mol dm ${ }^{-3} \mathrm{MSA}$ at $25^{\circ} \mathrm{C}$. Results are compared to a compressed '95-02' Al foam by Boomsa et al. ${ }^{52}$ 


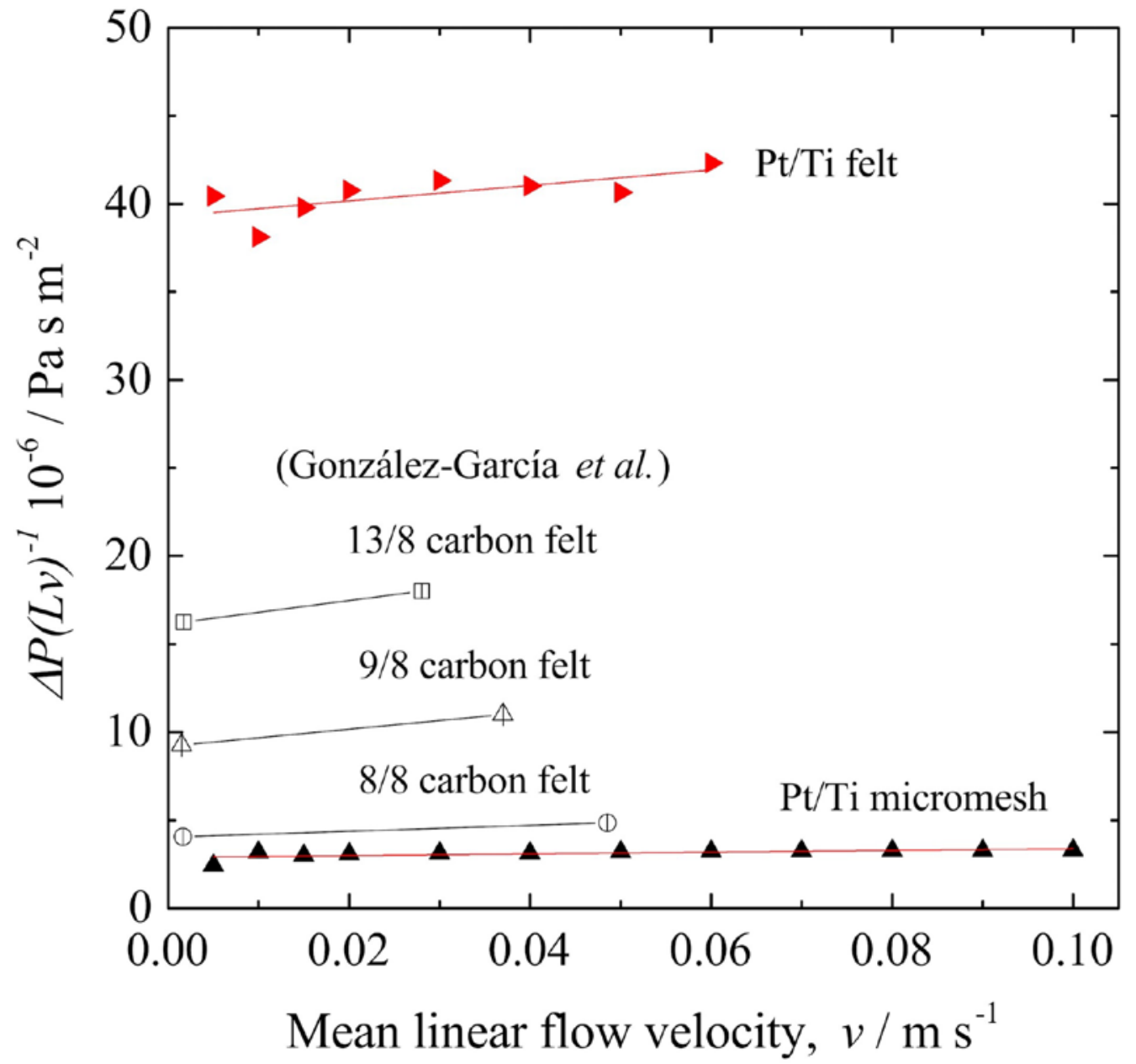

Figure 8. Ergun plots for the different electrode materials. Electrolyte composition: $0.8 \mathrm{~mol} \mathrm{dm}^{-3}$ Ce(III) in 4 mol dm ${ }^{-3}$ MSA at $25^{\circ} \mathrm{C}$. Results are compared to a carbon felt electrode with different electrode/compartment thickness compression ratios by González-García et al. ${ }^{59}$ 

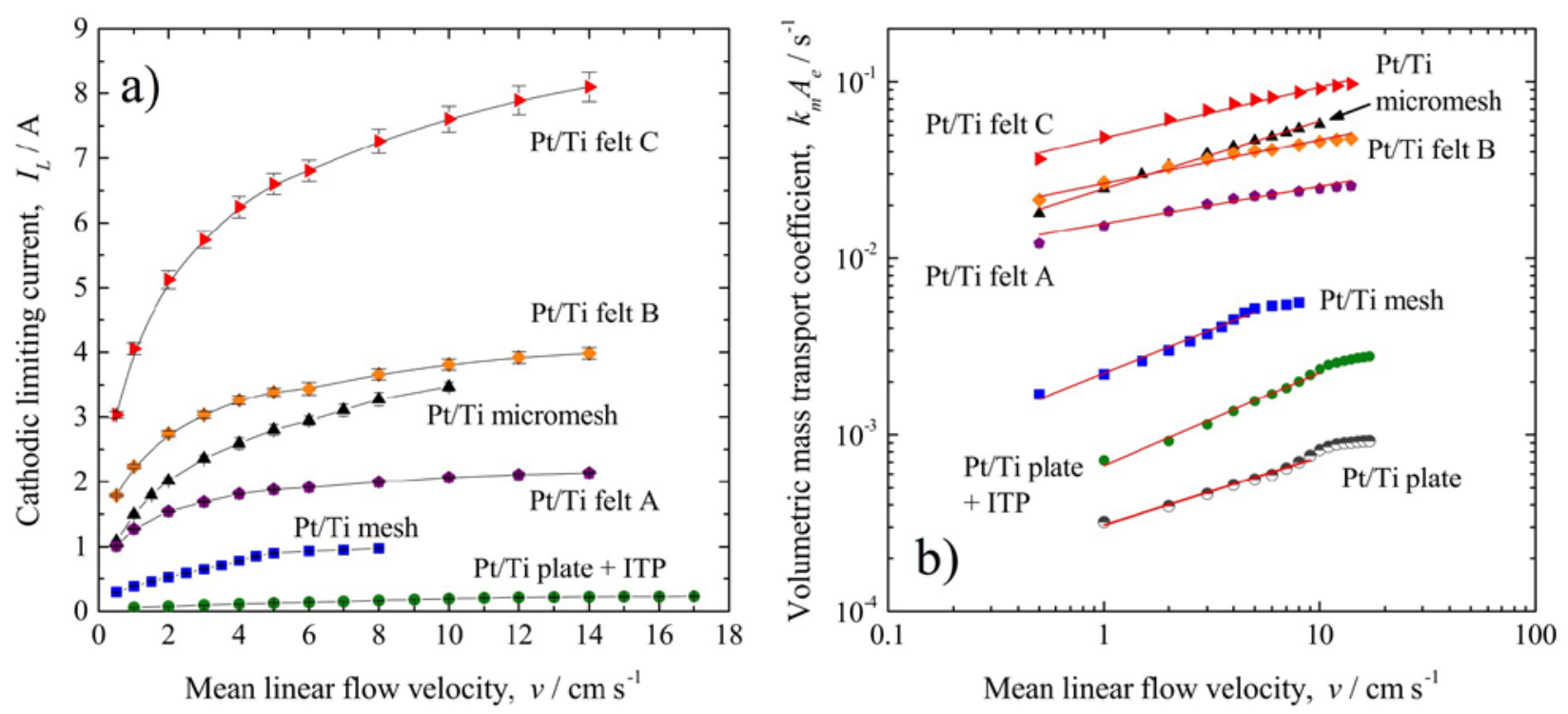

Figure 9. Determination of the electrochemical performance of Pt/Ti porous electrodes. a) Limiting current, $I 9$, for the reduction of $0.1 \mathrm{~mol} \mathrm{dm}^{-3} \mathrm{Ce}(\mathrm{IV})$ in an electrolyte containing $0.7 \mathrm{~mol}$ $\mathrm{dm}^{-3} \mathrm{Ce}(\mathrm{III})$ in $4 \mathrm{~mol} \mathrm{dm}^{-3} \mathrm{MSA}$ at $25^{\circ} \mathrm{C}$. b) Log-log plot of volumetric mass transport coefficient $k_{\$} A \&$ as a function of mean linear flow rate. 


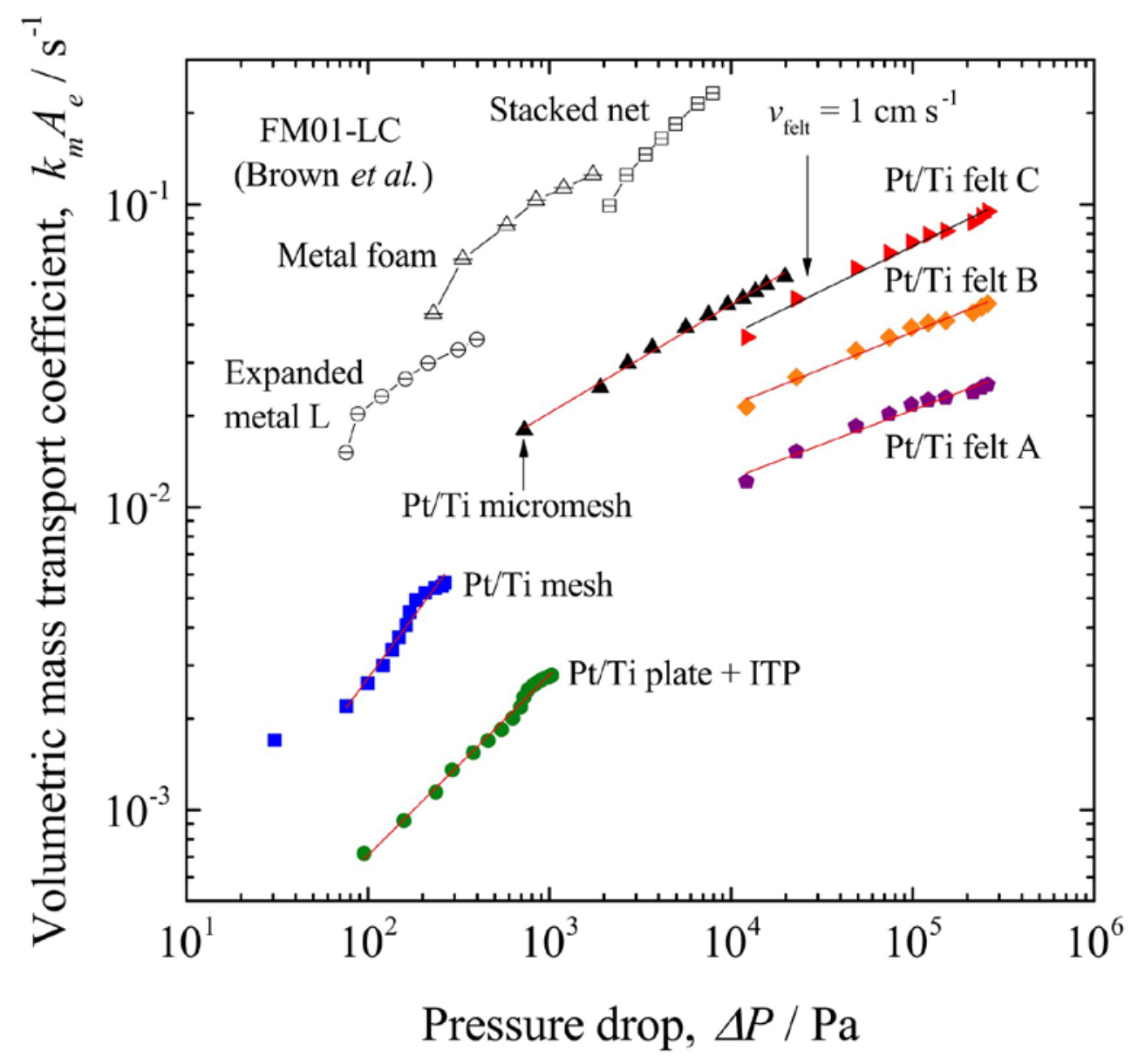

Figure 10. Volumetric mass transport coefficient as a function of pressure drop for different $\mathrm{Pt} / \mathrm{Ti}$ electrode materials. Current data for $k \$ A \&$ was obtained by chronoamperometry at $0.2 \mathrm{~V} v$ s. $\mathrm{Hg} \mid \mathrm{Hg}_{2} \mathrm{SO}_{4 \text { (satd) }}$ in $0.1 \mathrm{~mol} \mathrm{dm}^{-3} \mathrm{Ce}(\mathrm{IV})+0.7 \mathrm{~mol} \mathrm{dm}^{-3} \mathrm{Ce}$ (III) in $4 \mathrm{~mol} \mathrm{dm}^{-3} \mathrm{MSA}$ at $25^{\circ} \mathrm{C}$. Pressure drop measured in a solution containing $0.8 \mathrm{~mol} \mathrm{dm}^{-3} \mathrm{Ce}(\mathrm{III})$ in $4 \mathrm{~mol} \mathrm{dm}^{-3} \mathrm{MSA}$ at $25^{\circ} \mathrm{C}$. Results are compared to porous electrodes in the FM01-LC reactor with an electrolyte containing $5.0 \times 10^{-3} \mathrm{~mol} \mathrm{dm}^{-3}$ ferricyanide in $1.0 \mathrm{~mol} \mathrm{dm}^{-3} \mathrm{KOH}$ at $25^{\circ} \mathrm{C}^{19}$

\section{Tables}

Table 1. Dimensions and hydraulic characteristics of the porous platinised titanium electrodes in the 
rectangular channel flow cell. ITP: Inert turbulence promoters.

\begin{tabular}{|c|c|c|c|c|c|c|c|c|}
\hline Electrode & $\begin{array}{l}\text { Length, } \\
L / \mathrm{cm}\end{array}$ & $\begin{array}{l}\text { Breath, } \\
B / \mathrm{cm}\end{array}$ & $\begin{array}{c}\text { Height, } S \\
\quad / \mathrm{cm}\end{array}$ & $\begin{array}{c}\text { Equivalent } \\
\text { hydraulic } \\
\text { diameter, } \\
d_{\&} / \mathrm{cm}\end{array}$ & $\begin{array}{l}\text { rosity, } \\
\qquad \varepsilon\end{array}$ & $\begin{array}{l}\text { Volume, } \\
V_{\&} / \mathrm{cm}^{3}\end{array}$ & $\begin{array}{l}\text { Projected } \\
\text { area, } A-\mathrm{z} \\
\quad \mathrm{cm}^{2}\end{array}$ & $\begin{array}{l}\text { Cross- } \\
\text { ttional } \\
\text { A. / } \\
\mathrm{cm}^{2}\end{array}$ \\
\hline $\begin{array}{l}\text { Pt-Ti plate } \\
\text { + ITP }\end{array}$ & 6.0 & 4.0 & 0.36 & 0.65 & 0.78 & 8.5 & 24.0 & 1.42 \\
\hline Pt-Ti mesh & 6.0 & 4.2 & 0.74 & 1.26 & 0.71 & 18.7 & 25.2 & 3.11 \\
\hline $\begin{array}{c}\text { Pt-Ti } \\
\text { micromesh }\end{array}$ & 6.0 & 4.0 & 0.26 & 0.48 & 0.53 & 6.2 & 24.0 & 1.02 \\
\hline $\begin{array}{l}\text { Pt-Ti felt } \\
\text { (A, B and } \\
\text { C) }\end{array}$ & 6.0 & 4.0 & 0.36 & 0.66 & 0.80 & 8.64 & 24.0 & 1.44 \\
\hline
\end{tabular}

Table 2. Constants in the power law $\Delta P=d R e^{6}$ describing the relation between pressure drop and Reynolds number through platinised titanium porous electrodes. ITP: Inert turbulence promoters.

\begin{tabular}{cccc}
\hline Electrode & $d / \mathrm{Pa}$ & $h$ & Ref. \\
\hline Pt-Ti plate + ITP & 10.1 & 0.82 & This work \\
Pt-Ti mesh & 9.2 & 0.61 & This work \\
Pt-Ti micromesh & 114.6 & 1.07 & This work \\
Pt-Ti felt (A, B, C) & 1083.2 & 1.07 & This work
\end{tabular}




\begin{tabular}{|c|c|c|c|}
\hline $\begin{array}{l}\text { FM0l-LC reactor } \\
\text { (empty channel) }\end{array}$ & $6.9 \times 10^{-3}$ & 1.39 & [40] \\
\hline $\begin{array}{l}\text { FM0l-LC reactor } \\
\text { (promoter 'C') }\end{array}$ & $4.0 \times 10^{-2}$ & 1.25 & [40] \\
\hline $\begin{array}{c}\text { Colli et al. } \\
\text { (empty channel) }\end{array}$ & $2.0 \times 10^{-2}$ & 1.29 & [52] \\
\hline $\begin{array}{l}\text { Colli et al. } \\
\text { (promoter 'EPM2') }\end{array}$ & $4.1 \times 10^{-2}$ & 1.61 & [52] \\
\hline
\end{tabular}

Table 3. Ergun constants for the relation between pressure drop and Reynolds number through platinised titanium porous electrodes. ITP: Inert turbulence promoters. Carbon felt constants calculated from Gonzalez-García et al. ${ }^{[56]}$ The ratio denotes felt to channel thickness.

\begin{tabular}{cccc} 
Electrode & $M$ & $N$ & Ref. \\
\hline Pt-Ti micromesh & $4.90 \times 10^{6}$ & $2.89 \times 10^{6}$ & This work \\
Pt-Ti felt (A, B, C) & $4.39 \times 10^{7}$ & $3.93 \times 10^{7}$ & This work \\
Carbon felt 8/8 & $1.66 \times 10^{7}$ & $4.03 \times 10^{6}$ & {$[56]$} \\
Carbon felt 9/8 & $4.93 \times 10^{7}$ & $9.19 \times 10^{6}$ & {$[56]$} \\
Carbon felt 13/8 & $6.66 \times 10^{7}$ & $1.61 \times 10^{7}$ & {$[56]$} \\
\hline
\end{tabular}


Table 4. Constants in the power law $k_{\$} A_{\&}=p \Delta P @$ describing the relationship between pressure drop and volumetric mass transport coefficient through platinised titanium porous electrodes. ITP: Inert turbulence promoters.

\begin{tabular}{|c|c|c|c|}
\hline Electrode & $p / s^{-1}$ & $q$ & Ref. \\
\hline Pt-Ti plate + ITP & $4.6 \times 10^{-5}$ & 0.60 & This work \\
\hline Pt-Ti mesh & $6.5 \times 10^{-5}$ & 0.81 & This work \\
\hline Pt-Ti micromesh & $1.7 \times 10^{-3}$ & 0.36 & This work \\
\hline Pt-Ti felt A & $1.5 \times 10^{-3}$ & 0.23 & This work \\
\hline Pt-Ti felt B & $2.3 \times 10^{-3}$ & 0.24 & This work \\
\hline Pt-Ti felt C & $2.5 \times 10^{-3}$ & 0.29 & This work \\
\hline Expanded metal S & $7.2 \times 10^{-3}$ & 0.22 & [19] \\
\hline Expanded metal L & $2.7 \times 10^{-3}$ & 0.44 & [19] \\
\hline Twin grid & $2.7 \times 10^{-3}$ & 0.37 & [19] \\
\hline Metal foam & $3.9 \times 10^{-3}$ & 0.47 & [19] \\
\hline Stacked net & $7.6 \times 10^{-4}$ & 0.64 & [19] \\
\hline
\end{tabular}

